\title{
Propolis Extracts Enhance the Antimicrobial Activity of Slovenian: Chestnut, Forest and Flower Honeys
}

\author{
Bratko Filipič ${ }^{1}$, Klemen Rihar ${ }^{2}$, Dunja Exel Gregorič ${ }^{3}$, Lidija Gradišnik ${ }^{4}$, Adriana Pereyra ${ }^{5}$, Eva Ružić-Sabljić ${ }^{6}$, \\ Fabio Galeotti ${ }^{7}$, Nicola Volpi ${ }^{7}$, Alfredo Fachini ${ }^{8}$ and Hrvoje Mazija ${ }^{1}$ \\ 1. Croatian Institute for Experimental and Translational Oncology (CIETO), Koledinečka 03, Zagreb 10040, Croatia \\ 2. Retired, Chengdujska 4, Ljubljana 1000, Slovenia \\ 3. Retired, Glavarjeva 19, Ljubljana 1000, Slovenia \\ 4. Institute of Biomedical Sciences, Medical Faculty of Maribor, Taborska 8, Maribor 2000, Slovenia \\ 5. Medex D.o.o., Linhartova 49a, Ljubljana 1000, Slovenia \\ 6. Institute for Microbiology and Immunology, Medical Faculty of Ljubljana, Zloška 04, Ljubljana 1105, Slovenia \\ 7. Department of Life Sciences, University of Modena \& Regio Emilia, Modena 41125, Italy \\ 8. BNatural, Via Gran Sasso, Corbetta, MI 20011, Italy
}

\begin{abstract}
Because of the overuse and misuse of antibiotic, an increase in antibiotic resistance of pathogenic bacteria is evolving. Attention should be focused on natural alternatives to antibiotics, like propolis and honey. They all have strong antibacterial properties because of the active substances they contain. In the present study, the influence of P1 (water-soluble propolis (WSP) Greit 120) or P2 (phosphate buffer saline (PBS) propolis extract Lj. Center $\mathrm{pH}=8.0$ ) on antimicrobial activity of different Slovenian: chestnut honey $(\mathrm{CH})$, forest honeys $(\mathrm{FoH})$, and flower honey $(\mathrm{FlH})$ against various Gram-positive or Gram-negative bacteria and yeast Candida albicans are shown. Gram-positive bacteria used in the experiments were: methicillin-resistant Staphylococcus aureus, Staphylococcus aureus, Streptococcus pyogenes, Streptococcus agalactiae and Streptococcus mutans. The yeast was Candia albicans. Gram-negative bacteria used were: Escherichia coli, Pseudomonas aeruginosa and Acinetobacter baumanii. P1, P2, FoH, CH, FlH and their combinations were prepared in saline as $10 \%$ solutions. The composition of both propolis extracts and the three kinds of honey was determined by reverse-phase high-performance liquid chromatography (RP-HPLC). It expressed the antimicrobial activity as a minimal inhibitory concentration (MIC) in $\mathrm{mg} / \mathrm{mL}$. Each of the two propolis extracts showed antimicrobial activity when applied alone. Also, the application of each of honey yielded an antimicrobial activity in decreasing order: $\mathrm{CH}$, FoH and FlH honey. The combination of any of the propolis extract with any of the honey showed the additive antimicrobial effect on either Gram-positive or Gram-negative bacteria and on yeast Candida albicans. The effectiveness of P1 or P2 depends on their nature and from the sort of honey and is the highest in the case of $\mathrm{CH}$ followed by $\mathrm{FoH}$ and $\mathrm{FlH}$.
\end{abstract}

Key words: Honey, propolis, flavonoids, antimicrobial activity, enhancement.

\section{Introduction}

Propolis (sometimes also referred to as bee glue) is a resinous natural product, produced by bees (Apis mellifera), from vegetable parts and secretions. Bees use it mainly as a sealer to cover the hive interior and to repair fissures as well as to protect against pathogen

Corresponding author: Bratko Filipič, Ph.D., research fields: bee products and microbiology.

*Paper is devoted to the remembrance of Dr. Klemen Rihar who passed away on December 2018. microorganisms. Propolis is normally composed of $45 \%$ resins, $30 \%$ waxes and fatty acids, $10 \%$ essential oils, $5 \%$ pollen, and $10 \%$ organic compounds and minerals $[1,2]$. More than 300 compounds, among them flavonoids, glycans, phenolic acids and their esters, phenolic aldehydes, alcohols, ketones, terpenes, steroids, sugars, and amino acids have been detected in raw propolis, but the proportion of each compound differs greatly with botanical and geographical factors, as well as the collection season [3-5]. The compounds 
present in propolis are the explanation for some of its biological activities as antimicrobial and antioxidant one. They are responsible for the great interest by the pharmaceutical industry and health-food stores, being used in foods, beverages, cosmetics and medicine to improve health and prevent diseases [6, 7]. As propolis is a hard resinous substance, it cannot be consumed in its natural form. Its usual way of preparation is by powdering the resinous, followed by extraction in an alcoholic or aqueous medium.

Flavonoids are one of the most important constituents and can represent around $50 \%$ of the propolis contents, depending on the region where it is collected, since its characteristics are influenced by botanical, geographical factors and weather. The antioxidant activity of propolis from various geographic origins was studied and different activities were found for each region. Its properties were investigated confirming its antibacterial, antiviral, antifungal and anti protozoal activities among others. Due to its antimicrobial activity, ethanol propolis extracts inhibit the growth of Streptococcus sp. [8] and are more active against Gram-positive bacteria than against Gram-negative ones [9].

The effect of the $\mathrm{pH}$ variation during the extraction of flavonoids and polyphenols has been studied working with different vegetal species. The $\mathrm{pH}$ variation could have a positive or a negative effect on extraction, depending on the interaction of the polyphenols with other constituents of each plant.

The most common propolis in Brazil is usually collected in the southeast region, characterized as group 12 (Brazil has 12 different groups of propolis, with distinct characteristics), and presents a great number of soluble substances with antimicrobial activity against Staphylococcus aureus and Str. mutans. Activity of propolis originating from various geographic origins was studied and different activities were found specific for each region. Its properties were investigated confirming its antibacterial, antiviral, antifungal and anti protozoal activities.
Considering the widespread use of propolis, the objective was to evaluate the effect of $\mathrm{pH}$ variation on propolis extraction, prepared with water as a solvent.

Different $\mathrm{pH}$ values were tested to water as a solvent, and were compared with samples without $\mathrm{pH}$ variation. Final water extracts of propolis were quantified regarding flavonoids and phenol contents to verify the relation between the $\mathrm{pH}$ and water in the extraction efficiency. Analyses of antimicrobial and antioxidant activities show the strongest antimicrobial activity of propolis extract at $\mathrm{pH}=8.0[10]$.

Honey is a complementary remedy for the treatment of infected wounds particularly where conventional modern therapeutics fails. Among honey types, certainly, the most effective Manuka honey was reported to exhibit antimicrobial activity against pathogenic bacteria like: S. aureus and Helicobacter pylori making it promising agent for the treatment of wounds or even stomach ulcer [11]. The beneficial role of honey is attributed to the beneficial property that is comprised of high osmolarity, acidity (low $\mathrm{pH}$ ) and content of hydrogen peroxide $\left(\mathrm{H}_{2} \mathrm{O}_{2}\right)$ as well as non-peroxide components, i.e., the presence of phytochemical components, like methylglyoxal (MGO). The $\mathrm{H}_{2} \mathrm{O}_{2}$ is the most important antimicrobial agent in the honey. Its concentration is determined by relative levels of glucose oxidase, synthesized by the bee and catalase originating from flower pollen [12, 13]. Most types of honey generate $\mathrm{H}_{2} \mathrm{O}_{2}$ when diluted, because of the activation of the enzyme glucose oxidase that oxidizes glucose to gluconic acid and $\mathrm{H}_{2} \mathrm{O}_{2}$, which thus attributes the overall antimicrobial activity [14].

The healing properties of honey can be ascribed to the fact that it offers the antibacterial activity, maintains a moist wound environment to promote healing and has a high viscosity that helps to form a protective barrier to prevent infection $[15,16]$. On the other hand, proteins with glycosidase activity can induce tumor necrosis factor-alpha (TNF- $\alpha$ ) secretion 
by macrophages. This cytokine is known to induce the mechanism of wound healing.

In the present study, the influences of $\mathrm{P} 1$ (water-soluble propolis (WSP) Greit 120) or P2 (phosphate buffer saline (PBS) propolis extract $\mathrm{Lj}$. Center $\mathrm{pH}=8.0$ ) on the antimicrobial activity of different Slovenian honeys: chestnut honey $(\mathrm{CH})$, forest honey $(\mathrm{FoH})$ and flower honey $(\mathrm{FlH})$ against various Gram-positive or Gram-negative bacteria and yeast Candida albicans are shown.

\section{Materials and Methods}

\subsection{Samples}

2.1.1 Species of Microorganisms Used in the Experiments

Different clinical isolates of Gram-positive bacteria: methicillin-resistant $S$. aureus (MRSA), S. aureus, Str. pyogenes, Str. agalactiae, Str. mutans and yeast $C$. albicans were used. The Gram-negative clinical isolates were: Escherichia coli, Pseudomonas aeruginosa and Acinetobacter baumanii. All clinical isolates used in the experiments, were obtained from microbe collection of the Institute for Microbiology and Immunology, Medical Faculty in Ljubljana, Slovenia. All microbes were first cultivated on Mueller-Hinton agar at $37^{\circ} \mathrm{C}$ for $48 \mathrm{~h}$ and afterward, were transferred to Mueller-Hinton broth, until the concentration of $0.5 \mathrm{McF}$ arland was obtained.

\subsubsection{Propolis}

Two types of propolis extracts were used in this study. P1 by BNatural, Corbetta, Italy was used in dilution 1:10 w/v in saline. The P2 was prepared in the laboratory and also used in dilution $1: 10 \mathrm{w} / \mathrm{v}$ in saline.

\subsection{Methods}

\subsubsection{P1}

By the new technology developed by Fachini and Volpi [17, 18] the P1 was extracted. This new multi-step extraction technology is called dynamic multi extraction (M.E.D.). It allows modifying some parameters such as solvent degree, temperature, $\mathrm{pH}$, etc., during the extraction phase thanks to a series of modular equipment and according to the raw material to be worked out. The results are then standardized extracts richer in integral polyphenols (phenolic acids, bioflavonoid aglycons and glucosides). The propolis samples (P1) were processed as follows: (1) aqueous extraction, to remove waxes and impurities from raw materials, using a 1:1 solvent/propolis ratio, at $80{ }^{\circ} \mathrm{C}$ for $10 \mathrm{~h}$ and with 100 watt ultrasounds. After cooling at $8^{\circ} \mathrm{C}$, the solution was filtered with a $30 \mu \mathrm{m}$ filter; (2) three hydro-alcoholic extractions, one for each insoluble residue of the preceding extraction step, carried out using different alcoholic degrees and temperatures, from $4 \mathrm{~h}$ to $36 \mathrm{~h}$, with a fixed 1:1 solvent/propolis residue ratio. Each extraction step was followed by a sample cooling step at circa $15^{\circ} \mathrm{C}$, a filtration step with $30-50 \mu \mathrm{m}$ filters and a concentration step using a rotating evaporator, to obtain a soft mixture; (3) concentration: the combined extracts were mixed and concentrated to a residual humidity value ranging from $15 \%$ to $20 \%$ by weight; (4) dissolution in glycerin: the concentrated extracts were evaporated to remove ethanol. The dough was mixed with hot glycerin and water for $2 \mathrm{~h}$ within a mixer and then cooled at $10{ }^{\circ} \mathrm{C}$ to give a non-alcoholic liquid. After precipitation the solution was filtered twice, using a $30 \mu \mathrm{m}$ and a $10 \mu \mathrm{m}$ filter.

\subsubsection{P2}

The P2 was prepared as follows: (1) propolis sample "Lj. center" ( $10 \mathrm{~g})$ was frozen at $-40{ }^{\circ} \mathrm{C}$ for $3 \mathrm{~d}$; (2) partially refrozen sample was grounded in mortar and resuspended in $100 \mathrm{~mL}$ PBS with $\mathrm{pH} 8.0$; (3) the suspension was shaken at $37{ }^{\circ} \mathrm{C}$ for $5 \mathrm{~d}$ and it was grounded in mortar and shaken at $37{ }^{\circ} \mathrm{C}$ for additional $3 \mathrm{~d}$; (4) the suspension was put into $50 \mathrm{~mL}$ tubes and then put into microwave oven at $300 \mathrm{MW}$ for three times $\times 2$ min with 10 min break; (5) the P2 suspension was centrifuged at 5,000 rpm for $20 \mathrm{~min}$, $+4{ }^{\circ} \mathrm{C}$; (6) supernatant was sterilized by filtration 
through $0.2 \mu \mathrm{m}$ syringe filters and stored at $-20{ }^{\circ} \mathrm{C}$ till use.

2.2.3 Quantity of Caffeic Acid, Chrysin, Pinocembrin and Galangin in P1 and P2

The amounts of the caffeic acid, chrysin, pinocembrin and galangin in $\mathrm{P} 1$ and $\mathrm{P} 2$ were determined by the method of Urushisaki et al. [19] as follows: $1.0 \mathrm{mg}$ of caffeic acid, chrysin, pinocembrin and galangin were put and diluted to $10.0 \mathrm{~mL}$ with methanol. From this solution, $150 \mu \mathrm{L}$ of the sample was transferred into a vial and loaded with $1.350 \mu \mathrm{L}$ of methanol. Samples filtered through a $0.45 \mu \mathrm{m}$ filter were injected by $20 \mu \mathrm{L}$ into the reverse-phase high-performance liquid chromatography (RP-HPLC) column Purospher ${ }^{\circledR}$ Star RP-18 end-capped (5 $\left.\mu \mathrm{m}\right)$. Theirs separation was achieved with acetonitrile gradient in RP-HPLC column.

The P2 was analyzed on the Purospher ${ }^{\circledR}$ STAR RP-18 end-capped $(5 \mu \mathrm{m})$ RP-HPLC column. Its separation measured at $290 \mathrm{~nm}$, with acetonitrile gradient is presented in Fig. 1. The quantity of total flavonoids, caffeic acid, chrysin, pinocembrin and galangin in the experimental sample of P2 was calculated in comparison to standards.

2.2.4 Estimation of Total Flavonoid Content by Folin-Ciocalteu (FC) Colorimetric Method

The FC was performed by the method of Blainski et al. [20] and Filipič et al. [21] as follows: phenol compounds react with an FC reagent in a basic medium and colored product is formed. The absorbance is measured at $750 \mathrm{~nm}$. Results are expressed as $\mathrm{g}$ of caffeic acid per $100 \mathrm{~g}$ of the sample $(\mathrm{g} / 100 \mathrm{~g})$. Procedure goes like: pipette $200 \mu \mathrm{L}$ of sample or standard and adds $1.0 \mathrm{~mL}$ of FC reagent and $1.0 \mathrm{~mL}$ of $10 \% \mathrm{Na}_{2} \mathrm{CO}_{3}$. Mix well and after $1 \mathrm{~h}$ the absorbance at $750 \mathrm{~nm}$ is measured against water. Each sample and standard is analyzed in duplicate. The results are expressed as caffeic acid in $\mathrm{mg} / \mathrm{mL}$.

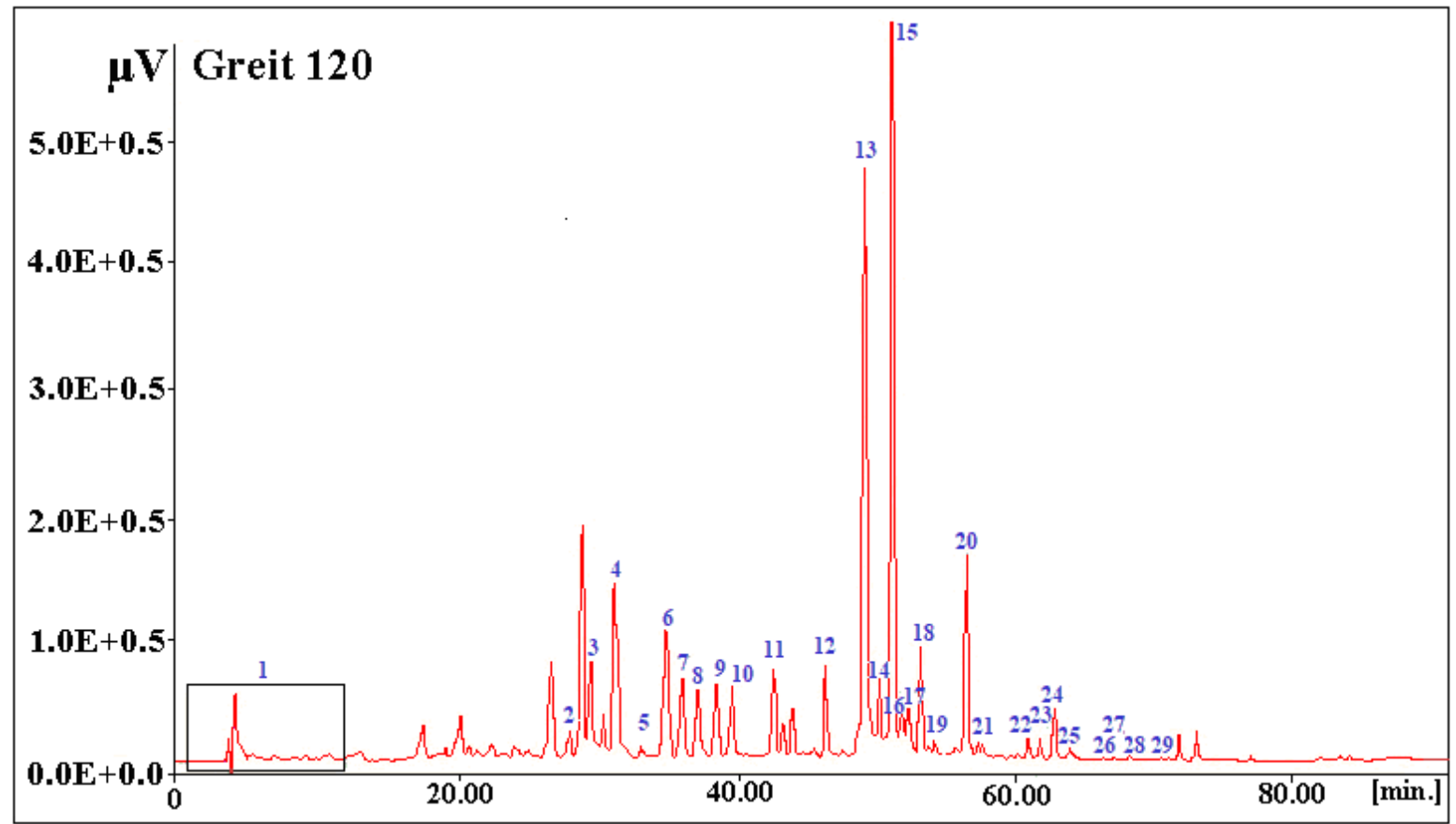

Fig. 1 HPLC-UV-ESI-MS504971 of flavonoid's profile of an average sample of P1.

1 = phenolic acids (caffeic, coumaric, ferulic, isoferulic); 2 = quercetin; 3 = pinobanksin 5-methyl ester; 4 = quercetin 3-methyl ester; 5 = pinobanksin; 6 = apigenin; $7=$ kaempferol; $8=$ isorhamnetin; $9=$ luteolin 5 -methyl ester; $10=$ quercetin 5-7-dimethyl ester; $11=$ galangin 5-methyl ester; 12 = quercetin 7-methyl ester; 13 = chrysin; 14 = pinocembrin; 15 = galangin; $16=$ pinobanksin-3-O-acetate; 17 = caffeic acid phenethyl ester (CAPE); 18 = metoxychrysin; 19 = pinobanksin-3-O-propionate; 20 = caffeic acid cinnamyl ester; 21 $=$ pinobanksin-3-O-butyrate; $22=$ pinobanksyn-3-O-pentenoate; $23=$ other pinobanksin derivative; $24=$ pinobanksin-3-O-hexanoate; $25=$ other pinobanksin derivative. 
2.2.5 Determination of the Minimal Inhibitory Concentration (MIC)

The MIC values determinations were performed according to Resazurin method [22, 23] as follows. Here, 96 well "U" profile microtitre plates $(8 \times 12$ wells) were used. Into the $2^{\text {nd }}$ column (eight wells) until the $12^{\text {th }}$ column, the $50 \mu \mathrm{L}$ of saline was put. Into the $1^{\text {st }}$ column (eight wells), $100 \mu \mathrm{L}$ of samples was put as follows: in the $1^{\text {st }}$ plate samples, in wells 1-4 and into wells $5-8$ in the $1^{\text {st }}$ column; in the $2^{\text {nd }}$ plate samples, in wells $9-11+$ untreated control in the $1^{\text {st }}$ column; into the $3^{\text {rd }}$ plate, penicillin, streptomycin, gentamycin and nystatin were put into wells in duplicate in the $1^{\text {st }}$ column. Then, $50 \mu \mathrm{L}$ was transferred from the $1^{\text {st }}$ column into the $2^{\text {nd }}, 3^{\text {rd }}$ and until $11^{\text {th }}$, where $50 \mu \mathrm{L}$ was discharged. Into each plate on each well, $50 \mu \mathrm{L}$ of test microorganisms in the concentration of 0.5 McFarland was added, and the plate was wrapped into aluminum foil and incubated for $48 \mathrm{~h}$ at $37{ }^{\circ} \mathrm{C}$. After incubation is finished, $20 \mu \mathrm{L}$ of Resazurin (Sigma-Aldrich) $(0.0028$ $\mathrm{g}$ of Resazurin dissolved in $10 \mathrm{~mL}$ of distilled water, to which $90 \mathrm{~mL}$ of eagle's minimal essential medium (EMEM) was added) and plates were wrapped into aluminums foil and incubated at room temperature for 4 $\mathrm{h}$. The following is the growth inhibition of bacteria after the staining with Resazurin. The Resazurin has a blue color. The absence of microbe's growth inhibition results in the change of the color of Resazurin from blue to pink. MIC was determined as the highest dilution, resulting in no or the minimal change in color. For example, in the $7^{\text {th }}$ well, there is a change from pink to blue. So, color change in the $7^{\text {th }}$ well with dilution 1:64, $\mathrm{MIC}=1 \times 10 / 64=0.156 \mathrm{mg} / \mathrm{mL}$.

2.2.6 Percent of Microbial Growth Inhibition

The percent of microbial growth inhibition was measured by the two-fold dilution of the substance, from the $1^{\text {st }}$ to $11^{\text {th }}$ well in the row, and then different microbes were added ( 0.5 McFarland). After $24 \mathrm{~h}$ of incubation at $37{ }^{\circ} \mathrm{C}, 20 \mu \mathrm{L}$ of Resazurin was added. The plates were incubated and wrapped in aluminums foil for $4 \mathrm{~h}$ at room temperature. After the incubation, it was detected, in which well the growth inhibition occurred. The per cent of microbial growth inhibition was calculated as follows: if the growth inhibition was found in the $4^{\text {th }}$ well, the percent of bacterial/fungal growth inhibition $=4 / 12 \times 100=33.33 \%$.

\subsubsection{Scheme of the Experiments}

The following combinations between P1, P2 and Slovenian $\mathrm{CH}, \mathrm{FoH}$ and $\mathrm{FlH}$ were used in the experiments (Table 1).

\subsection{Statistical Analysis}

The statistical significance was calculated by the two-tailed Student's $t$-test. In order to compare the difference in susceptibility between honey alone and honey with the addition of P1 or P2, the MICs for different honey samples were pooled.

\section{Results}

\subsection{Molecular Composition of P1 Determined by HPLC-UV-ESI-MS 504971}

Fig. 1 shows the HPLC-UV-ESI-MS504971 profile and in Table 2, the molecular composition of P1 in a very precise way.

Table 1 Scheme of the experiments.

\begin{tabular}{llll}
\hline & & $\mathrm{P} 1^{\mathrm{a}}$ & $\mathrm{P} 2^{\mathrm{b}}$ \\
\cline { 3 - 4 } & $10 \%$ solution in saline & $10 \%$ solution in saline \\
\hline $\mathrm{CH}^{\mathrm{c}}$ & $10 \%$ solution in saline & $90 \%$ of $\mathrm{CH}+10 \%$ of $\mathrm{P} 1$ & $90 \%$ of $\mathrm{CH}+10 \%$ of $\mathrm{P} 2$ \\
$\mathrm{FoH}^{\mathrm{d}}$ & $10 \%$ solution in saline & $90 \%$ of $\mathrm{FoH}+10 \%$ of $\mathrm{P} 1$ & $90 \%$ of $\mathrm{FoH}+10 \%$ of $\mathrm{P} 2$ \\
$\mathrm{FlH}^{\mathrm{e}}$ & $10 \%$ solution in saline & $90 \%$ of $\mathrm{FlH}+10 \%$ of $\mathrm{P} 1$ & $90 \%$ of $\mathrm{FlH}+10 \%$ of $\mathrm{P} 2$ \\
\hline
\end{tabular}

${ }^{\mathrm{a}}$ WSP Greit $120 ;{ }^{\mathrm{b}} \mathrm{PBS}$ extract of propolis Ljubljana Center $\mathrm{pH} 8.0 ;{ }^{\mathrm{c}}$ chestnut honey; ${ }^{\mathrm{d}}$ forest honey; ${ }^{\mathrm{e}}$ flower honey. 
Table 2 The molecular composition of P1 determined by HPLC-UV-ESI-MS504971.

\begin{tabular}{|c|c|c|}
\hline Number on chromatogram & Polyphenols species & Greit $120(\% \mathrm{w} / \mathrm{v})$ \\
\hline 1 & Phenolic acids (caffeic, coumaric, ferulic, isoferulic) & 0.5 \\
\hline 2 & Quercetin & 1.5 \\
\hline 3 & Pinobanksin 5-methyl ester & 1.4 \\
\hline 4 & Quercetin 3-methyl ester & 5.0 \\
\hline 5 & Pinobanksin & 4.0 \\
\hline 6 & Apigenin & 1.1 \\
\hline 7 & Kaempferol & 3.8 \\
\hline 8 & Isorhamnetin & 3.3 \\
\hline 9 & Luteolin 5-methyl ester & 2.1 \\
\hline 10 & Quercetin 5-7-dimethyl ester & 1.7 \\
\hline 11 & Galangin 5-methyl ester & 1.1 \\
\hline 12 & Quercetin 7-methyl ester & 3.2 \\
\hline 13 & Chrysin & 5.0 \\
\hline 14 & Pinocembrin & 2.9 \\
\hline 15 & Galangin & 7.5 \\
\hline 16 & Pinobanksin-3-O-acetate & 9.5 \\
\hline 17 & CAPE & 0.3 \\
\hline 18 & Metoxychrysin & 1.1 \\
\hline 19 & Pinobanksin-3-O-propionate & 1.2 \\
\hline 20 & Caffeic acid cinnamyl ester & 0.2 \\
\hline 21 & Pinobanksin-3-O-butyrate & 5.7 \\
\hline 22 & Pinobanksyn-3-O-pentenoate & 2.6 \\
\hline 23 & Other pinobanksin derivative & 0.7 \\
\hline 24 & Pinobanksin-3-O-hexanoate & 0.3 \\
\hline 25 & Other pinobanksin derivative & 0.4 \\
\hline 26 & Other pinobanksin derivative & 3.3 \\
\hline 27 & Other pinobanksin derivative & 0.5 \\
\hline 28 & Other pinobanksin derivative & 0.2 \\
\hline 29 & Other pinobanksin derivative & 0.7 \\
\hline Total identified polyphenols & & 70.8 \\
\hline Phenolic acids and derivatives & & 1.0 \\
\hline Flavones and flavonols & & 36.4 \\
\hline Flavanones and dihydroflavonoles & & 33.4 \\
\hline
\end{tabular}

Source: data were kindly provided by Prof. Dr. Nicola Volpi (Department of Life Sciences, University of Modena \& Reggio Emilia, Modena 41125, Italy).

\subsection{Quantity of Caffeic Acid, Chrysin, Pinocembrin and Galangin in $P 2$}

The P2 was analyzed on the Purospher ${ }^{\circledR}$ STAR RP-18 end-capped ( $5 \mu \mathrm{m})$ RP-HPLC column.

The quantity of total flavonoids, caffiec acid, chrysin, pinocembrin and galangin in $\mathrm{mg} / \mathrm{mL}$ is shown in Fig. 2 and are as follows: total flavonoids $10.42 \pm$ $1.23 \mathrm{mg} / \mathrm{mL}$, caffeic acid $2.44 \pm 0.18 \mathrm{mg} / \mathrm{mL}$, caffeic acid 1, $1.43 \pm 0.11 \mathrm{mg} / \mathrm{mL}$, chrysin $0.15 \pm 0.08$ $\mathrm{mg} / \mathrm{mL}$, pinocembrin $0.46 \pm 0.04 \mathrm{mg} / \mathrm{mL}$ and galangin $0.62 \pm 0.05 \mathrm{mg} / \mathrm{mL}$.

\subsection{Physico-Chemical Properties of Slovenian Honeys: $\mathrm{FoH}, \mathrm{CH}$ and $\mathrm{FlH}$}

The physico-chemical properties of Slovenian $\mathrm{CH}$, $\mathrm{FlH}$ and $\mathrm{FoH}$ were obtained from doctoral dissertations of Bertoncelj [24]. 


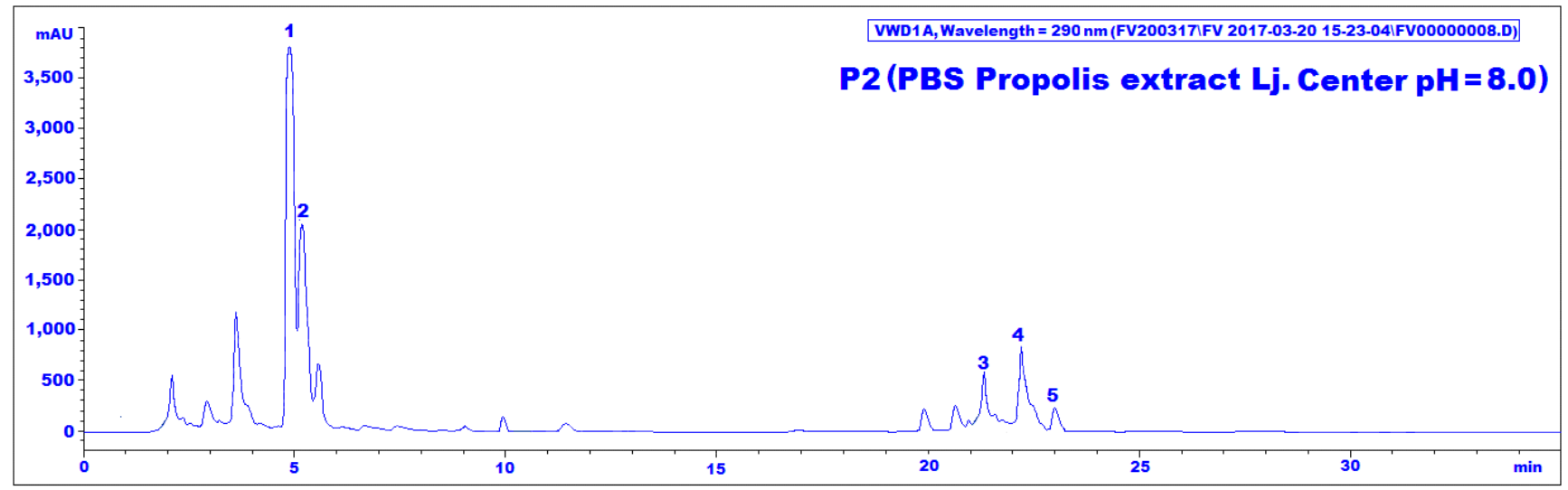

Fig. 2 The presence of different flavonoids in the P2.

$1=$ caffeic acid; 2 = caffeic acid $1 ; 3=$ crysin; $4=$ pinocembrin; $5=$ galangin.

\subsection{Antimicrobial Activity of P1, P2, FoH, CH and $\mathrm{FlH}$}

\subsubsection{Antimicrobial Activity of P1}

Recently, P1 became important because of being a buffer for problems with respiratory health. In the treatment of upper respiratory tract the hydrogliceric extract of P1 is used. Besides, P1 shows also quite strong antimicrobial activity, which is stronger against Gram-positive bacteria than against Gram-negative bacteria. The antimicrobial activity of $\mathrm{P} 1$ is present in Table 3 and Fig. 3. For the Gram-positive bacteria, the range of MIC is between $0.007 \pm 0.001 \mathrm{mg} / \mathrm{mL}$ and $0.015 \pm 0.007 \mathrm{mg} / \mathrm{mL}$. Against Gram-negative bacteria, MIC of P1 lies between $0.015 \pm 0.007$ $\mathrm{mg} / \mathrm{mL}$ and $0.031 \pm 0.015 \mathrm{mg} / \mathrm{mL}$. For C. albicans, the MIC is $0.015 \pm 0.007 \mathrm{mg} / \mathrm{mL}$. The antibacterial activity of propolis is usually strong against Gram-positive bacteria and C. albicans.

\subsubsection{Antimicrobial Activity of $\mathrm{P} 2$}

Propolis extract $\mathrm{P} 2$ presented in Table 3 and Fig. 3 shows the antimicrobial activity for the Gram-positive bacteria where the range of MIC $(\mathrm{mg} / \mathrm{mL})$ lays between $0.007 \pm 0.0035$ and $0.031 \pm 0.015$. For the Gram-negative bacteria, the MIC $(\mathrm{mg} / \mathrm{mL})$ is between $0.031 \pm 0.015$ and $0.062 \pm 0.015$. MIC $(\mathrm{mg} / \mathrm{mL})$ for $C$. albicans is $0.031 \pm 0.015$.

\subsection{Antimicrobial Activity of Slovenian Kinds of Honey}

In Table 3 the antimicrobial activities of different Slovenian kinds of honey are shown.

\subsubsection{CH}

In concentration of $10 \%$ in saline, the antibacterial activity of Slovenian $\mathrm{CH}$ was stronger (Fig. 4) for Gram-positive bacteria with MIC $(\mathrm{mg} / \mathrm{mL})$ of $0.015 \pm$ 0.007 and $0.062 \pm 0.015$, than for Gram-negative bacteria, where the value of MIC $(\mathrm{mg} / \mathrm{mL})$ lies between $0.015 \pm 0.007$ and $0.031 \pm 0.015$. The MIC ( $\mathrm{mg} / \mathrm{mL}$ ) for C. albicans is $0.015 \pm 0.007$.

\subsection{2 $\mathrm{FoH}$}

In concentration of $10 \%$ in saline, the antibacterial activity is surprisingly the same for Gram-positive and Gram-negative bacteria (Fig. 4). MIC (mg/mL) values are between $0.015 \pm 0.007$ and $0.062 \pm 0.015$. Quite strong the $\mathrm{FoH}$ is against $C$. albicans with $\mathrm{MIC}$ $(\mathrm{mg} / \mathrm{mL}) 0.007 \pm 0.0035$.

\subsection{3 $\mathrm{FlH}$}

The weakest among Slovenian honeys is the FlH (Fig. 4). The MIC (mg/mL) values for Gram-positive bacteria lays between $0.007 \pm 0.0035$ and $0.250 \pm$ 0.030 and for Gram-negative bacteria between $0.031 \pm$ 0.015 and $0.125 \pm 0.015$. The MIC $(\mathrm{mg} / \mathrm{mL})$ value for C. albicans is also weak $0.062 \pm 0.015$. 
Table 3 MIC (mg/mL) and growth index (GI)-Inhibition \% for different microbes depending on P1, P2, CH, FoH, FlH and combinations of CH + P1, FoH + P1, FlH + P1, CH + P2, FoH + P2, FlH + P2, penicillin, streptomycin, gentamycin and nystatin.

\begin{tabular}{|c|c|c|c|c|c|c|c|c|c|c|c|c|c|c|c|c|c|c|}
\hline \multirow{3}{*}{$\begin{array}{l}10 \% \text { sample } \\
\text { of: }\end{array}$} & \multicolumn{10}{|c|}{ Gram-positive bacteria } & \multicolumn{6}{|c|}{ Gram-negative bacteria } & \multirow{2}{*}{\multicolumn{2}{|c|}{$\frac{\text { Yeast }}{\text { dida albicans }}$}} \\
\hline & \multicolumn{2}{|c|}{$\mathrm{MRSA}^{\mathrm{a}}$} & \multicolumn{2}{|c|}{$\begin{array}{c}\text { Staphylococcus } \\
\text { aureus }\end{array}$} & \multicolumn{2}{|c|}{$\begin{array}{c}\text { Streptococcus } \\
\text { pyogenes }\end{array}$} & \multicolumn{2}{|c|}{ Str. agalactiae } & \multicolumn{2}{|c|}{ Str. mutans } & \multicolumn{2}{|c|}{ Escherichia coli } & \multicolumn{2}{|c|}{$\begin{array}{c}\text { Pseudomonas } \\
\text { aeruginosa }\end{array}$} & \multicolumn{2}{|c|}{$\begin{array}{c}\text { Acinetobacter } \\
\text { baumanii }\end{array}$} & & \\
\hline & $\begin{array}{l}\mathrm{MIC} \\
(\mathrm{mg} / \mathrm{mL})\end{array}$ & $\begin{array}{l}\text { GI-Inh. } \\
(\%)\end{array}$ & $\begin{array}{l}\mathrm{MIC} \\
(\mathrm{mg} / \mathrm{mL})\end{array}$ & $\begin{array}{l}\text { GI-Inh. } \\
(\%)\end{array}$ & $\begin{array}{l}\mathrm{MIC} \\
(\mathrm{mg} / \mathrm{mL})\end{array}$ & $\begin{array}{l}\text { GI-Inh. } \\
(\%)\end{array}$ & $\begin{array}{l}\mathrm{MIC} \\
(\mathrm{mg} / \mathrm{mL})\end{array}$ & $\begin{array}{l}\text { GI-Inh. } \\
(\%)\end{array}$ & $\begin{array}{l}\mathrm{MIC} \\
(\mathrm{mg} / \mathrm{mL})\end{array}$ & $\begin{array}{l}\text { GI-Inh. } \\
(\%)\end{array}$ & $\begin{array}{l}\mathrm{MIC} \\
(\mathrm{mg} / \mathrm{mL})\end{array}$ & $\begin{array}{l}\text { GI-Inh. } \\
(\%)\end{array}$ & $\begin{array}{l}\mathrm{MIC} \\
(\mathrm{mg} / \mathrm{mL}\end{array}$ & $\begin{array}{l}\text { GI-Inh. } \\
(\%)\end{array}$ & $\begin{array}{l}\mathrm{MIC} \\
(\mathrm{mg} / \mathrm{mL})\end{array}$ & $\begin{array}{l}\text { GI-Inh. } \\
(\%)\end{array}$ & $\begin{array}{l}\mathrm{MIC} \\
(\mathrm{mg} / \mathrm{mL})\end{array}$ & $\begin{array}{l}\text { GI-Inh. } \\
(\%)\end{array}$ \\
\hline $\mathrm{P} 1^{\mathrm{b}}$ & $\begin{array}{l}0.007 \pm \\
0.001\end{array}$ & 66.66 & $\begin{array}{l}0.015 \pm \\
0.007\end{array}$ & 58.0 & $\begin{array}{l}0.015 \pm \\
0.007\end{array}$ & 58.0 & $\begin{array}{l}0.015 \pm \\
0.007\end{array}$ & 58.0 & $\begin{array}{l}0.007 \pm \\
0.001\end{array}$ & 66.66 & $\begin{array}{l}0.031 \pm \\
0.015\end{array}$ & 50.0 & $\begin{array}{l}0.015 \pm \\
0.007\end{array}$ & 58.3 & $\begin{array}{l}0.031 \pm \\
0.015\end{array}$ & 50.0 & $\begin{array}{l}0.031 \pm \\
0.015\end{array}$ & 41.6 \\
\hline $\mathrm{P} 2^{\mathrm{c}}$ & $\begin{array}{l}0.015 \pm \\
0.007\end{array}$ & 58.3 & $\begin{array}{l}0.031 \pm \\
0.015\end{array}$ & 50.0 & $\begin{array}{l}0.031 \pm \\
0.007\end{array}$ & 50.0 & $\begin{array}{l}0.007 \pm \\
0.0035\end{array}$ & 66.66 & $\begin{array}{l}0.015 \pm \\
0.007\end{array}$ & 58.3 & $\begin{array}{l}0.015 \pm \\
0.007\end{array}$ & 58.3 & $\begin{array}{l}0.015 \pm \\
0.007\end{array}$ & 58.3 & $\begin{array}{l}0.015 \pm \\
0.007\end{array}$ & 58.3 & $\begin{array}{l}0.031 \\
\pm 0.015\end{array}$ & 50.0 \\
\hline $\mathrm{CH}^{\mathrm{d}}$ & $\begin{array}{l}0.031 \pm \\
0.007\end{array}$ & 50.0 & $\begin{array}{l}0.015 \pm \\
0.007\end{array}$ & 58.0 & $\begin{array}{l}0.015 \pm \\
0.007\end{array}$ & 58.0 & $\begin{array}{l}0.031 \pm \\
0.015\end{array}$ & 50.0 & $\begin{array}{l}0.062 \pm \\
0.015\end{array}$ & 41.6 & $\begin{array}{l}0.031 \pm \\
0.007\end{array}$ & 50.0 & $\begin{array}{l}0.031 \pm \\
0.015\end{array}$ & 50.0 & $\begin{array}{l}0.015 \pm \\
0.007\end{array}$ & 58.3 & $\begin{array}{l}0.015 \pm \\
0.007\end{array}$ & 58.3 \\
\hline $\mathrm{FoH}^{\mathrm{e}}$ & $\begin{array}{l}0.062 \pm \\
0.015\end{array}$ & 41.6 & $\begin{array}{l}0.015 \pm \\
0.007\end{array}$ & 58.0 & $\begin{array}{l}0.031 \pm \\
0.007\end{array}$ & 50.0 & $\begin{array}{l}0.015 \pm \\
0.007\end{array}$ & 58.3 & $\begin{array}{l}0.031 \pm \\
0.015\end{array}$ & 50.0 & $\begin{array}{l}0.031 \pm \\
0.007\end{array}$ & 50.0 & $\begin{array}{l}0.062 \pm \\
0.015\end{array}$ & 41.6 & $\begin{array}{l}0.015 \pm \\
0.007\end{array}$ & 58.3 & $\begin{array}{l}0.007 \pm \\
0.0035\end{array}$ & 66.66 \\
\hline $\mathrm{FlH}^{\mathrm{f}}$ & $\begin{array}{l}0.250 \pm \\
0.030\end{array}$ & 25.0 & $\begin{array}{l}0.031 \pm \\
0.007\end{array}$ & 50.0 & $\begin{array}{l}0.031 \pm \\
0.007\end{array}$ & 50.0 & $\begin{array}{l}0.007 \pm \\
0.0035\end{array}$ & 66.6 & $\begin{array}{l}0.125 \pm \\
0.015\end{array}$ & 33.3 & $\begin{array}{l}0.062 \pm \\
0.0015\end{array}$ & 41.6 & $\begin{array}{l}0.125 \pm \\
0.015\end{array}$ & 33.3 & $\begin{array}{l}0.031 \pm \\
0.031\end{array}$ & 41.6 & $\begin{array}{l}0.062 \pm \\
0.015\end{array}$ & 41.6 \\
\hline $\mathrm{CH}+\mathrm{P} 1$ & $\begin{array}{l}0.003 \pm \\
0.0015\end{array}$ & 75.0 & $\begin{array}{l}0.007 \pm \\
0.0035\end{array}$ & 66.6 & $\begin{array}{l}0.003 \pm \\
0.0015\end{array}$ & 75.0 & $\begin{array}{l}0.007 \pm \\
0.0035\end{array}$ & 66.6 & $\begin{array}{l}0.031 \pm \\
0.007\end{array}$ & 50.0 & $\begin{array}{l}0.007 \pm \\
0.0035\end{array}$ & 66.6 & $\begin{array}{l}0.003 \pm \\
0.0015\end{array}$ & 75.0 & $\begin{array}{l}0.003 \pm \\
0.0015\end{array}$ & 75.0 & $\begin{array}{l}0.007 \pm \\
0.0035\end{array}$ & 66.6 \\
\hline $\mathrm{FoH}+\mathrm{P} 1$ & $\begin{array}{l}0.003 \pm \\
0.0015\end{array}$ & 75.0 & $\begin{array}{l}0.007 \pm \\
0.0035\end{array}$ & 66.6 & $\begin{array}{l}0.007 \pm \\
0.0035\end{array}$ & 66.6 & $\begin{array}{l}0.007 \pm \\
0.0035\end{array}$ & 66.6 & $\begin{array}{l}0.015 \pm \\
0.007\end{array}$ & 58.0 & $\begin{array}{l}0.003 \pm \\
0.0015\end{array}$ & 75.0 & $\begin{array}{l}0.007 \pm \\
0.0035\end{array}$ & 66.6 & $\begin{array}{l}0.007 \pm \\
0.0035\end{array}$ & 66.6 & $\begin{array}{l}0.003 \pm \\
0.0015\end{array}$ & 75.0 \\
\hline$+\mathrm{P} 1$ & $\begin{array}{l}0.015 \pm \\
0.007\end{array}$ & 58.3 & $\begin{array}{l}0.015 \pm \\
0.007\end{array}$ & 58.3 & $\begin{array}{l}0.031 \pm \\
0.015\end{array}$ & 50.0 & $\begin{array}{l}0.031 \pm \\
0.015\end{array}$ & 50.0 & $\begin{array}{l}0.031 \pm \\
0.015\end{array}$ & 50.0 & $\begin{array}{l}0.062 \pm \\
0.015\end{array}$ & 41.6 & $\begin{array}{l}0.015 \pm \\
0.007\end{array}$ & 58.3 & $\begin{array}{l}0.062 \pm \\
0.015\end{array}$ & 41.6 & $\begin{array}{l}0.031 \pm \\
0.015\end{array}$ & 41.6 \\
\hline $\mathrm{CH}+\mathrm{P} 2$ & $\begin{array}{l}0.015 \pm \\
0.007\end{array}$ & 58.3 & $\begin{array}{l}0.015 \pm \\
0.007\end{array}$ & 58.3 & $\begin{array}{l}0.007 \pm \\
0.0036\end{array}$ & 66.6 & $\begin{array}{l}0.003 \pm \\
0.0015\end{array}$ & 75.0 & $\begin{array}{l}0.015 \pm \\
0.007\end{array}$ & 58.3 & $\begin{array}{l}0.031 \pm \\
0.015\end{array}$ & 50.0 & $\begin{array}{l}0.007 \pm \\
0.0035\end{array}$ & 66.6 & $\begin{array}{l}0.003 \pm \\
0.0015\end{array}$ & 75.0 & $\begin{array}{l}0.015 \pm \\
0.007\end{array}$ & 58.3 \\
\hline $\mathrm{FoH}+\mathrm{P} 2$ & $\begin{array}{l}0.007 \pm \\
0.0035\end{array}$ & 66.6 & $\begin{array}{l}0.003 \pm \\
0.0015\end{array}$ & 75.0 & $\begin{array}{l}0.007 \pm \\
0.0036\end{array}$ & 66.8 & $\begin{array}{l}0.007 \pm \\
0.0035\end{array}$ & 66.6 & $\begin{array}{l}0.003 \pm \\
0.0015\end{array}$ & 75.0 & $\begin{array}{l}0.007 \pm \\
0.0036\end{array}$ & 66.6 & $\begin{array}{l}0.003 \pm \\
0.0015\end{array}$ & 75.0 & $\begin{array}{l}0.007 \pm \\
0.0035\end{array}$ & 66.6 & $\begin{array}{l}0.003 \pm \\
0.0015\end{array}$ & 75.0 \\
\hline $\mathrm{FlH}+\mathrm{P} 2$ & $\begin{array}{l}0.031 \pm \\
0.007\end{array}$ & 50.0 & $\begin{array}{l}0.015 \pm \\
0.007\end{array}$ & 58.3 & $\begin{array}{l}0.015 \pm \\
0.007\end{array}$ & 58.3 & $\begin{array}{l}0.031 \pm \\
0.007\end{array}$ & 50.0 & $\begin{array}{l}0.031 \pm \\
0.007\end{array}$ & 50.0 & $\begin{array}{l}0.015 \pm \\
0.007\end{array}$ & 58.3 & $\begin{array}{l}0.015 \pm \\
0.007\end{array}$ & 58.3 & $\begin{array}{l}0.062 \pm \\
0.015\end{array}$ & 41.6 & $\begin{array}{l}0.015 \pm \\
0.007\end{array}$ & 58.3 \\
\hline $\begin{array}{l}\text { Penicillin } \\
(1: 10)\end{array}$ & $\begin{array}{l}5.000 \pm \\
0.016\end{array}$ & 16.66 & $\begin{array}{l}2.500 \pm \\
0.260\end{array}$ & 25.00 & $\begin{array}{l}0.312 \pm \\
0.040\end{array}$ & 50.00 & $\begin{array}{l}2.500 \pm \\
0.260\end{array}$ & 25.00 & $\begin{array}{l}1.897 \pm \\
0.174\end{array}$ & 28.00 & $\begin{array}{l}0.156 \pm \\
0.040\end{array}$ & 58.33 & $\begin{array}{l}0.625 \pm \\
0.016\end{array}$ & 41.66 & $\begin{array}{l}0.312 \pm \\
0.040\end{array}$ & 50.00 & & \\
\hline $\begin{array}{l}\text { Streptomycin } \\
(1: 10)\end{array}$ & $\begin{array}{l}0.019 \pm \\
0.004\end{array}$ & 83.33 & $\begin{array}{l}0.009 \pm \\
0.004\end{array}$ & 91.66 & $\begin{array}{l}0.019 \pm \\
0.004\end{array}$ & 83.33 & $\begin{array}{l}0.009 \pm \\
0.004\end{array}$ & 91.66 & $\begin{array}{l}0.009 \pm \\
0.004\end{array}$ & 91.66 & $\begin{array}{l}0.039 \pm \\
0.008\end{array}$ & 75.00 & $\begin{array}{l}0.009 \pm \\
0.004\end{array}$ & 91.66 & $\begin{array}{l}0.009 \pm \\
0.004\end{array}$ & 91.66 & & \\
\hline $\begin{array}{l}\text { Gentamycin } \\
(1: 10)\end{array}$ & $\begin{array}{l}0.019 \pm \\
0.004\end{array}$ & 83.33 & $\begin{array}{l}0.009 \pm \\
0.004\end{array}$ & 91.66 & $\begin{array}{l}0.039 \pm \\
0.008\end{array}$ & 75.00 & $\begin{array}{l}0.009 \pm \\
0.004\end{array}$ & 91.66 & $\begin{array}{l}0.009 \pm \\
0.004\end{array}$ & 91.66 & $\begin{array}{l}0.078 \pm \\
0.008\end{array}$ & 66.66 & $\begin{array}{l}0.009 \pm \\
0.004\end{array}$ & 91.66 & $\begin{array}{l}0.019 \pm \\
0.004\end{array}$ & 83.33 & & \\
\hline $\begin{array}{l}\text { Nystatin } \\
(1: 10)\end{array}$ & & & & & & & & & & & & & & & & & $\begin{array}{l}0.019 \pm \\
0.004\end{array}$ & 83.33 \\
\hline
\end{tabular}

$\mathrm{a}=$ meticillin-resistant Staphylococcus aureus; $\mathrm{b}=$ WSP Greit 120; $\mathrm{c}=$ PBS extract Lj. Center $\mathrm{pH}=8.0 ; \mathrm{d}=$ chestnut honey; $\mathrm{e}=$ forest honey; $\mathrm{f}=$ flower honey. 
Propolis Extracts Enhance the Antimicrobial Activity of Slovenian: Chestnut, Forest and Flower Honeys

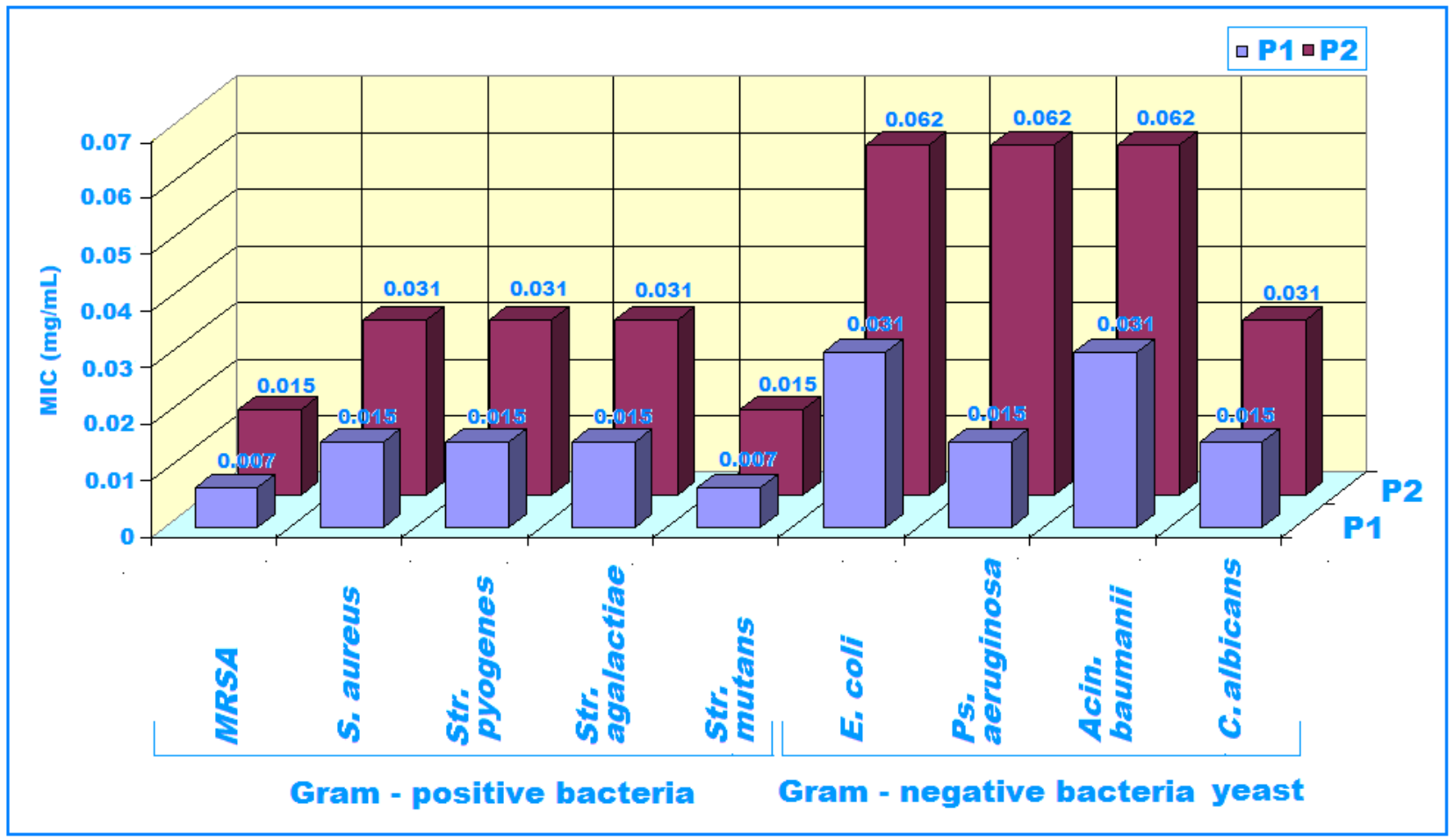

Fig. 3 The antimicrobial activity (MIC $\mathrm{mg} / \mathrm{mL}$ ) of P1 versus P2 against Gram-positive, Gram-negative bacteria and yeast C. albicans.

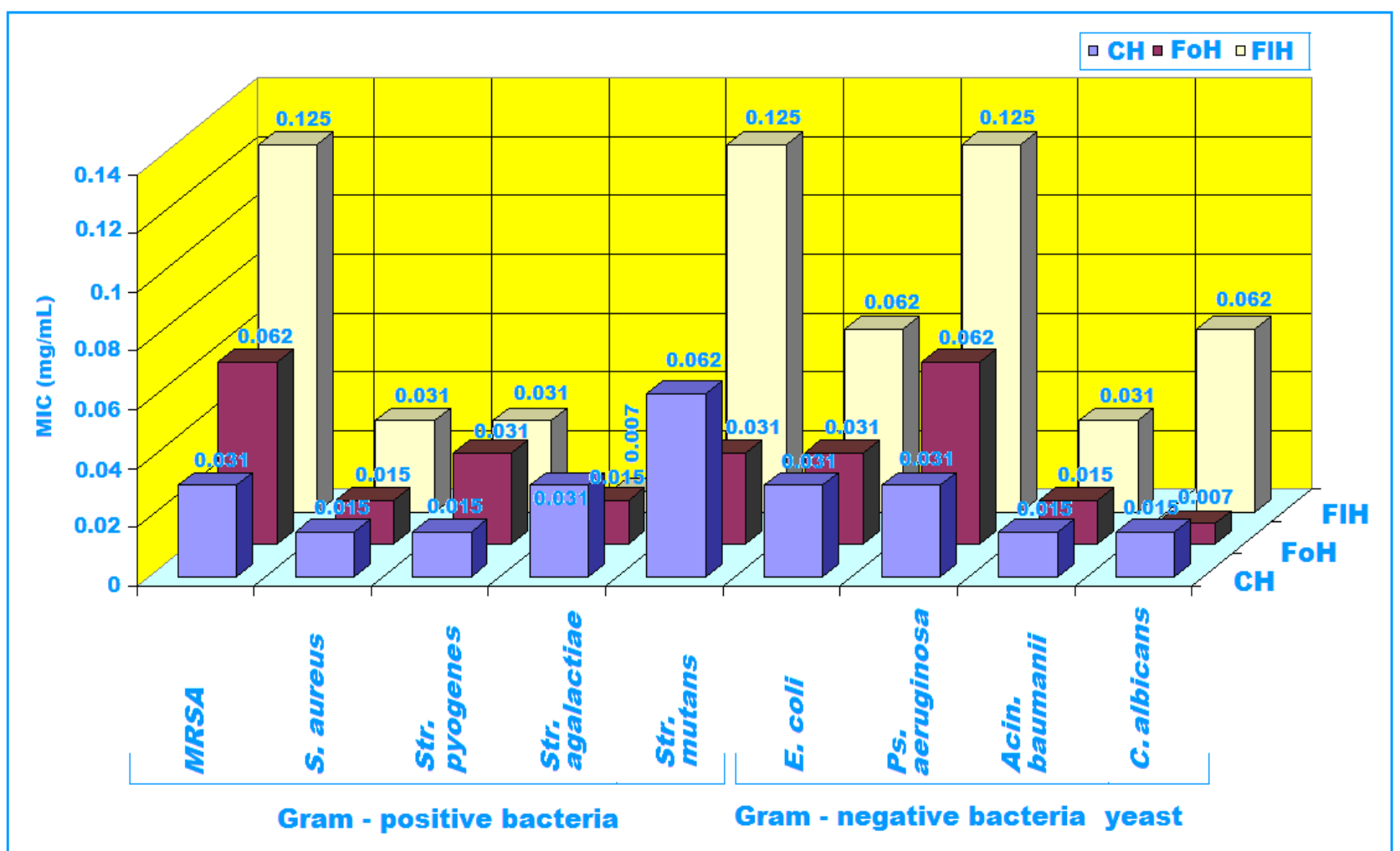

Fig. 4 The antimicrobial activity (MIC in $\mathrm{mg} / \mathrm{mL}$ ) of Slovenian $\mathrm{CH}$, FoH and FlH against Gram-positive, Gram-negative bacteria and yeast $C$. albicans. 


\subsection{Enhancing Effect of P1 on Antimicrobial Activity of Slovenian Honeys}

3.6.1 Enhancing Effect of P1 on Antimicrobial Activity of $\mathrm{CH}$

The combination of the $\mathrm{P} 1$ with Slovenian $\mathrm{CH}$ shows the following data (Fig. 5) about MIC (mg/mL) values: for Gram-positive bacteria MIC $(\mathrm{mg} / \mathrm{mL})$ was between $0.003 \pm 0.0015$ and $0.031 \pm 0.0035$. In the case of Gram-negative bacteria the MIC $(\mathrm{mg} / \mathrm{mL})$ lays between $0.003 \pm 0.0015$. The value of MIC $(\mathrm{mg} / \mathrm{mL})$ for C. albicans is $0.007 \pm 0.0035$.

3.6.2 Enhancing Effect of P1 on Antimicrobial Activity of $\mathrm{FoH}$

Combination of the P1 and Slovenian $\mathrm{FoH}$ shows (Fig. 6) that for Gram-positive bacteria MIC $(\mathrm{mg} / \mathrm{mL})$ was between $0.003 \pm 0.0015$ and $0.015 \pm 0.007$. For Gram-negative bacteria the MIC $(\mathrm{mg} / \mathrm{mL})$ lays between $0.003 \pm 0.0015$ and $0.007 \pm 0.0035$. MIC ( $\mathrm{mg} / \mathrm{mL}$ ) for C. albicans is $0.003 \pm 0.0015$.
3.6.3 Enhancing Effect of P1 on Antimicrobial Activity of FlH

Combination of the P1 and Slovenian $\mathrm{FlH}$ shows (Fig. 7) that for Gram-positive bacteria MIC $(\mathrm{mg} / \mathrm{mL})$ was between $0.015 \pm 0.0070$ and $0.031 \pm 0.0035$. For Gram-negative bacteria the MIC lays between $0.015 \pm$ 0.0070 and $0.062 \pm 0.015$. MIC $(\mathrm{mg} / \mathrm{mL})$ for $C$. albicans is $0.031 \pm 0.015$.

\subsection{Enhancing Effect of P2 on Antimicrobial Activity of Slovenian Honeys}

3.7.1 Enhancing Effect of P2 on Antimicrobial Activity of $\mathrm{CH}$

Combination of PBS extract $\mathrm{P} 2$ and $\mathrm{CH}$ gives the following MIC $(\mathrm{mg} / \mathrm{mL})$ values: for Gram-positive bacteria $0.003 \pm 0.0015$ and $0.015 \pm 0.007$; for Gram-negative bacteria the MIC $(\mathrm{mg} / \mathrm{mL})$ range (Fig. 5) is between $0.003 \pm 0.0015$ and $0.031 \pm 0.0035$. The MIC $(\mathrm{mg} / \mathrm{mL})$ for C. albicans is $0.015 \pm 0.007$.

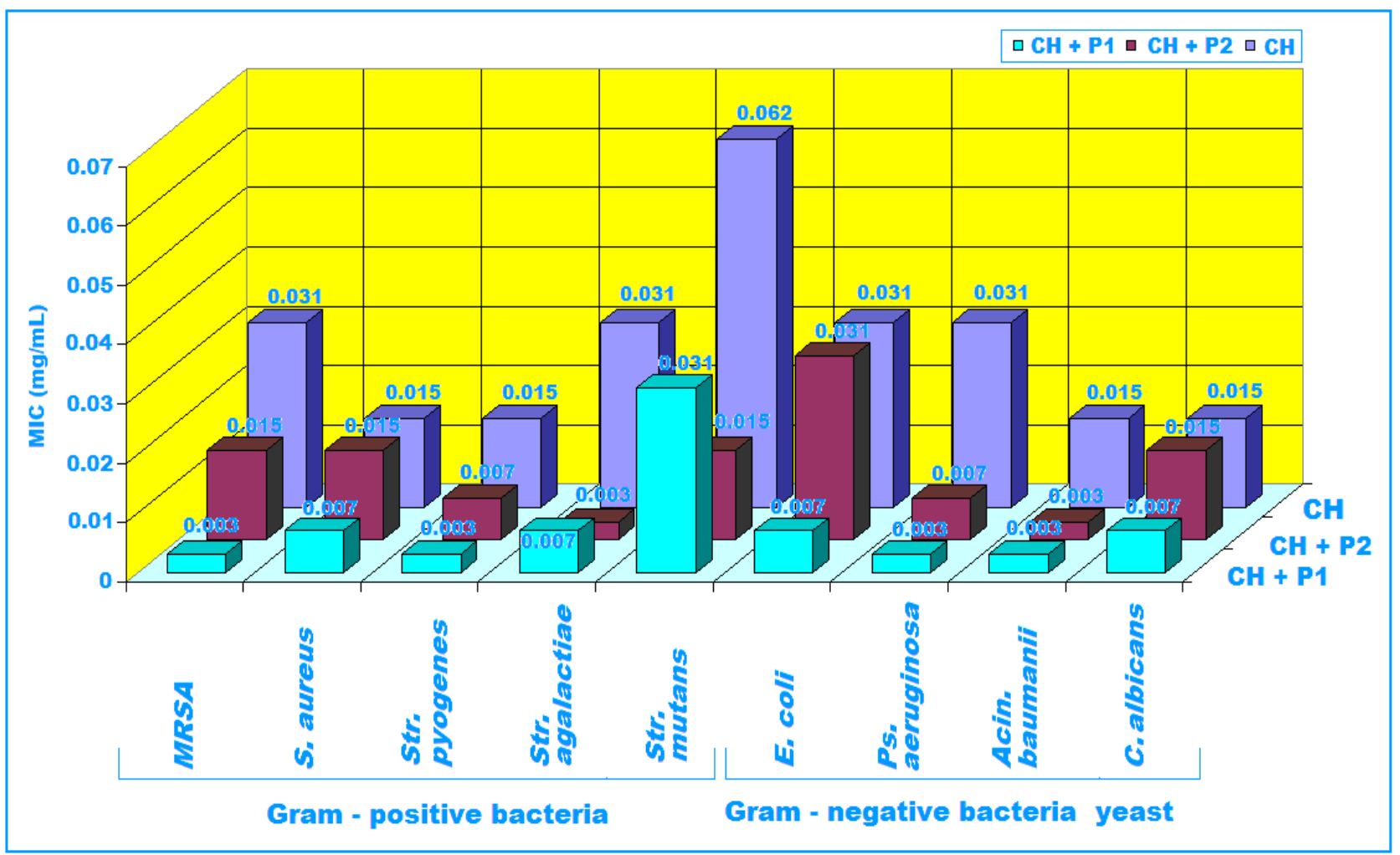

Fig. 5 Enhancing influence of $\mathrm{P} 1$ or $\mathrm{P} 2$ on the antimicrobial activity (MIC in $\mathrm{mg} / \mathrm{mL}$ ) of $\mathrm{CH}$ against Gram-positive, Gram-negative bacteria and yeast $C$. albicans. 
Propolis Extracts Enhance the Antimicrobial Activity of Slovenian:

Chestnut, Forest and Flower Honeys

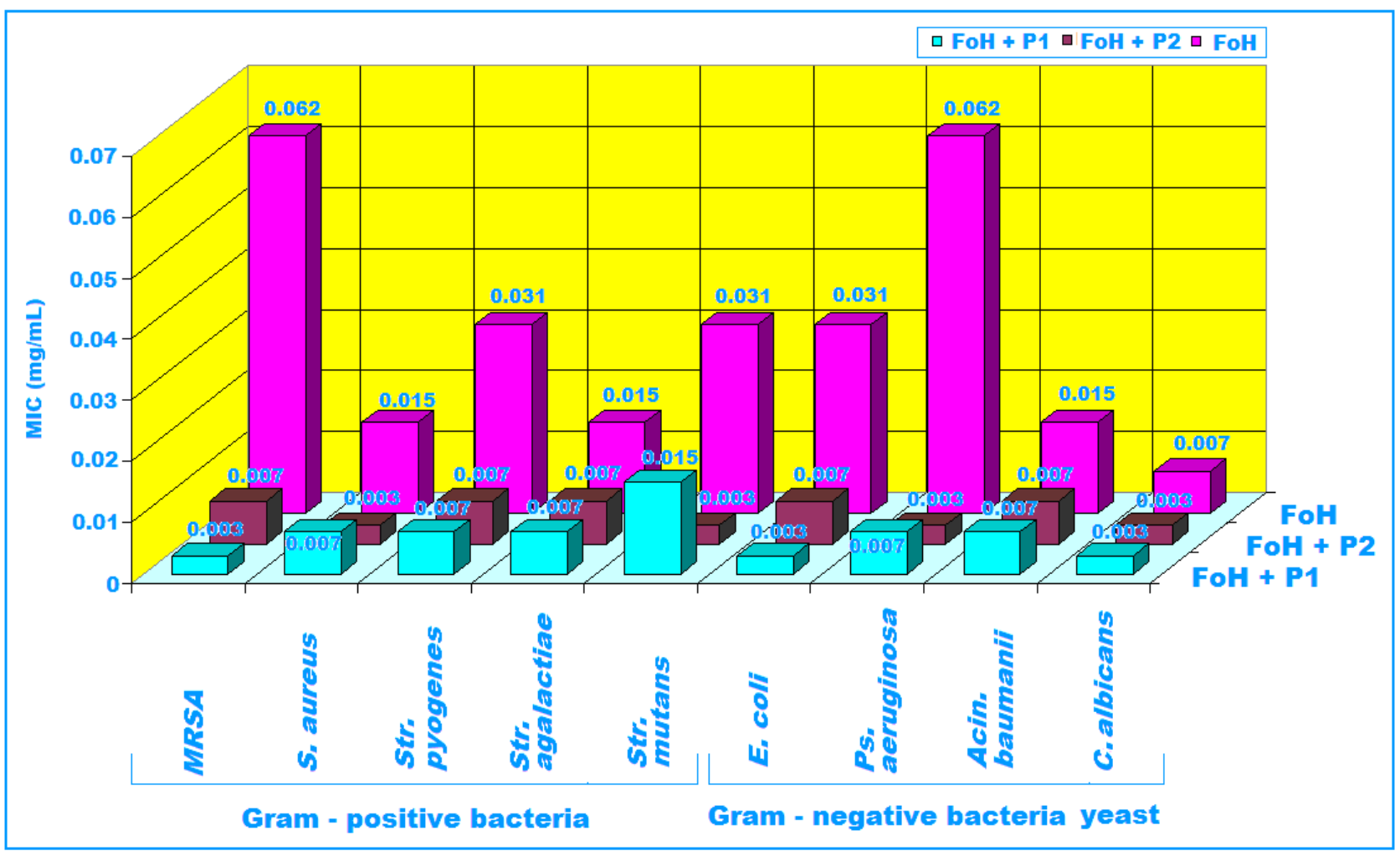

Fig. 6 Enhancing influence of $\mathrm{P} 1$ or $\mathrm{P} 2$ on the antimicrobial activity (MIC in $\mathrm{mg} / \mathrm{mL}$ ) of FoH against Gram-positive, Gram-negative bacteria and yeast $C$. albicans.

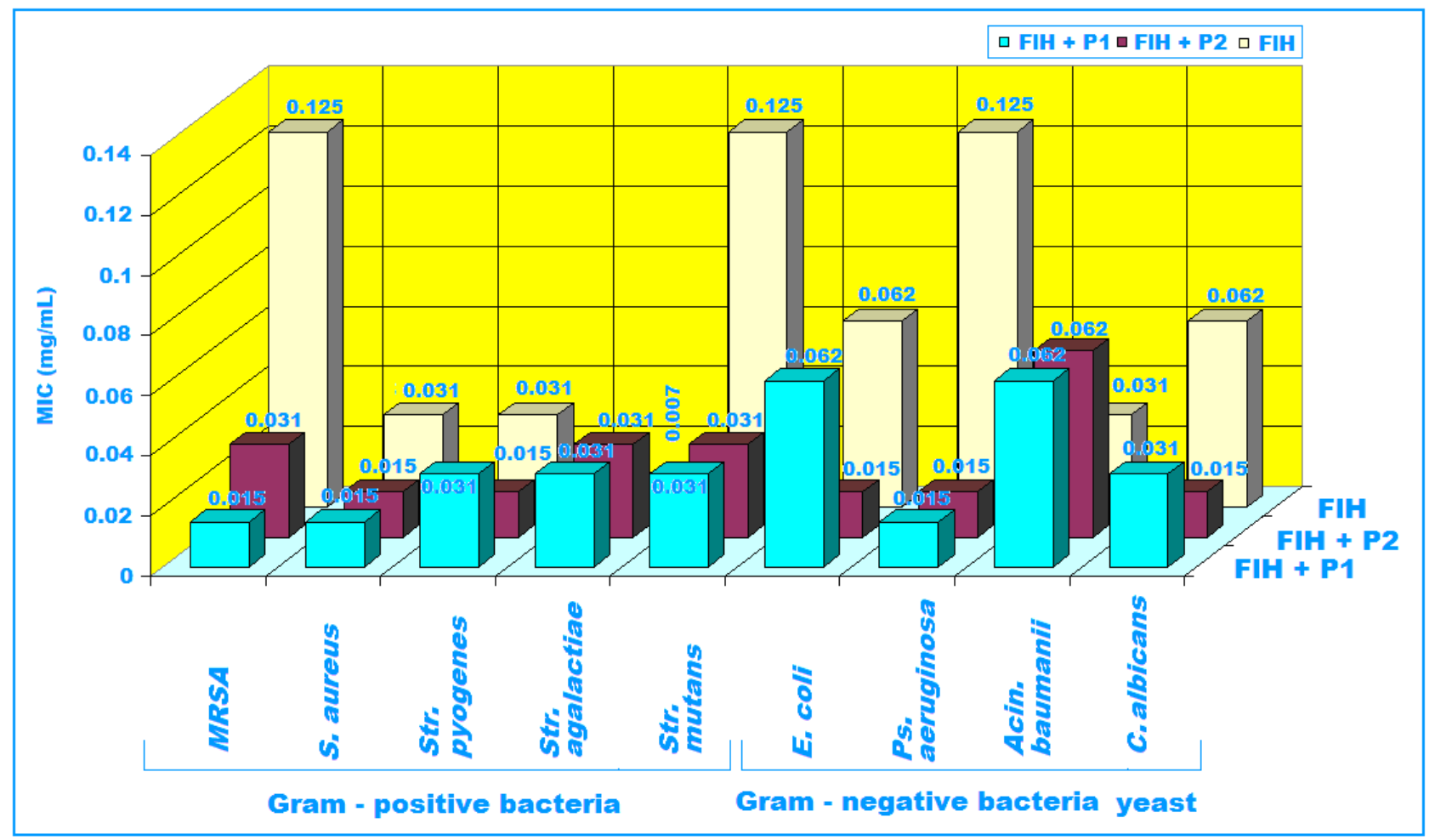

Fig. 7 Enhancing influence of $P 1$ or $P 2$ on the antimicrobial activity (MIC in $\mathrm{mg} / \mathrm{mL}$ ) of FlH against Gram-positive, Gram-negative bacteria and yeast $C$. albicans. 
3.7.2 Enhancing Effect of P2 on Antimicrobial Activity of $\mathrm{FoH}$

Combinations of PBS extract $\mathrm{P} 2$ and $\mathrm{FoH}$ gives the following $\mathrm{MIC}(\mathrm{mg} / \mathrm{mL})$ values (Fig. 6): for Gram-positive bacteria $0.003 \pm 0.0015$ and $0.007 \pm$ 0.0035. The MIC (mg/mL) values for Gram-negative bacteria are between $0.003 \pm 0.0015$ and $0.007 \pm$ 0.0035 , and are surprisingly the same as for Gram-positive bacteria. The MIC $(\mathrm{mg} / \mathrm{mL})$ for yeast $C$. albicans is $0.003 \pm 0.0015$.

3.7.3 Enhancing Effect of P2 on Antimicrobial Activity of $\mathrm{FlH}$

The combination of $\mathrm{P} 2$ and $\mathrm{FlH}$ gives the range of MIC (mg/mL) values (Fig. 7) for Gram-positive bacteria between $0.015 \pm 0.007$ and $0.031 \pm 0.0035$. In the case of Gram-negative bacteria MIC $(\mathrm{mg} / \mathrm{mL})$ values are between $0.015 \pm 0.007$ and $0.062 \pm 0.015$. The MIC $(\mathrm{mg} / \mathrm{mL})$ for C. albicans is $0.015 \pm 0.007$.

\subsection{Effectiveness of $P 1$ versus $P 2$ Added to $C H$}

The effectiveness of $\mathrm{P} 1$ versus $\mathrm{CH}$ can be seen in Table 4. The P1 added to $\mathrm{CH}$ is better than $\mathrm{P} 2$ added to $\mathrm{CH}$ as follows (Fig. 8): for Gram-positive bacteria, $9.00 \times$ (MRSA), 2.143× (S. aureus), 2.334× (Str. pyogenes), $0.429 \times$ (Str. agalactiae), $0.484 \times$ (Str. mutans); for Gram-negative bacteria, 4.429× (E. coli $)$, $2.334 \times($ Ps. aeruginosa $), 1.000 \times($ Acin. baumanii $)$ and for $C$. albicans $2.143 \times$.

\subsection{Effectiveness of $P 1$ versus $P 2$ Added to FoH}

$\mathrm{P} 1$ added to $\mathrm{FoH}$ is better than $\mathrm{P} 2$ added to $\mathrm{FoH}$ as follows (Fig. 8): for Gram-positive bacteria, 2.334× (MRSA), $0.492 \times(S$. aureus $), 1.000 \times($ Str. pyogenes $)$, $1.000 \times($ Str. agalactiae) and $0.200 \times($ Str. mutans $)$; for Gram-negative bacteria, $2.334 \times($ E. coli $), 0.429 \times(P S$. aeruginosa), 1.000× (Acin. baumanii) and for $C$. albicans $1.000 \times$.

\subsection{Effectiveness of P1 versus P2 Added to FlH}

The $\mathrm{P} 1$ added to $\mathrm{FlH}$ is better than $\mathrm{P} 2$ added to $\mathrm{FlH}$ as follows (Fig. 8): for Gram-positive bacteria, 2.067×
(MRSA), $1.000 \times($ S. aureus $), 0.484 \times($ Str. pyogenes $)$, $1.000 \times($ Str. agalactiae $)$ and $1.000 \times($ Str. mutans $)$; for Gram-negative bacteria, $0.242 \times($ E. coli $), 1.000 \times(P S$. aeruginosa), $1.000 \times$ (Acin. baumanii) and for $C$. albicans $0.484 \times$.

\section{Discussion}

The propolis is classified into two groups according to the differences of their components: one is a Brazilian type rich in $p$-cumaric acid derivatives, the other is a European type rich in flavonoids [25]. This present study reveals that propolis samples taken from different areas in Turkey posses similar characteristics from both groups. The total phenolic content was determined in comparison with standard gallic acid and the results expressed in terms of $\mathrm{mg}$ GAE/g propolis. Total phenolic content of propolis samples was found to be $115-210 \mathrm{mg}$ gallic acid/g of propolis extract by using FC method. All the propolis samples, except the Artvin sample (P10), possessed a high level of phenolic compound. Analyzed propolis samples contain an extensive number of phenolic compounds, and each sample has a distinctive profile. The amount and type of phenolic agents depend on the floral origin of propolis and they exhibit a wide range of biological effects and act as natural antioxidants and antimicrobials. The propolis samples contains a great percentage of benzoic acid (7.37-13.94 mg/mL), ferulic acid (22.3-574.11 $\mathrm{mg} / \mathrm{mL})$, abscisic acid (31.48-585.57 mg/mL), caffeic acids (125.94-465.81 $\mathrm{mg} / \mathrm{mL})$ and $p$-coumaric acid $(0.48-1.44 \mathrm{mg} / \mathrm{mL}) . \mathrm{In}$ small amounts, gallic acid (7.01-4.85 mg/mL), vanillic acid (3.16-33.38 $\mathrm{mg} / \mathrm{mL})$ proto-catheuic acid (4.01-27.08 $\mathrm{mg} / \mathrm{mL})$, chlorogenic acid (6.32-53.46 $\mathrm{mg} / \mathrm{mL}$ ) and $p$-hydroxybenzoic acid (41.32-387.13 $\mathrm{mg} / \mathrm{mL})$. In minor amounts, syringic acid (0.25-0.48 $\mathrm{mg} / \mathrm{mL})$ and $o$-coumaric acid $(0.48-1.45 \mathrm{mg} / \mathrm{mL})$ were found. It seems that the ferulic acid exhibits the potent antioxidant capacity in vitro and in vivo. The analyses of the total phenolic content of Slovenian propolis extract P2 show $102.42 \pm 1.23 \mathrm{mg} / \mathrm{mL}$. Analysis of 
Table 4 Effectiveness of $\mathrm{CH}+\mathbf{P} 2$ versus $\mathrm{CH}+\mathbf{P 1}$, FoH + P2 versus FoH + P1 and FlH + P2 versus FIH + P1.

\begin{tabular}{|c|c|c|c|c|c|c|c|c|c|c|c|c|c|c|c|c|c|c|}
\hline \multirow{3}{*}{$\begin{array}{l}10 \% \text { sample } \\
\text { of: }\end{array}$} & \multicolumn{10}{|c|}{ Gram-positive bacteria } & \multicolumn{6}{|c|}{ Gram-negative bacteria } & \multirow{2}{*}{\multicolumn{2}{|c|}{$\frac{\text { Yeast }}{\text { C. albicans }}$}} \\
\hline & \multicolumn{2}{|c|}{ MRSA $^{a}$} & \multicolumn{2}{|c|}{ S. aureus } & \multicolumn{2}{|c|}{ Str.pyogenes } & \multicolumn{2}{|c|}{ Str. agalactiae } & \multicolumn{2}{|c|}{ Str. mutans } & \multicolumn{2}{|c|}{ E. coli } & \multicolumn{2}{|c|}{ Ps. aeruginosa } & \multicolumn{2}{|c|}{ Acin. baumanii } & & \\
\hline & $\begin{array}{l}\begin{array}{l}\text { MIC } \\
(\mathrm{mg} / \mathrm{mL})\end{array} \\
\end{array}$ & $\begin{array}{l}\text { GI-Inh. } \\
(\%)\end{array}$ & $\begin{array}{l}\begin{array}{l}\text { MIC } \\
(\mathrm{mg} / \mathrm{mL})\end{array} \\
\end{array}$ & $\begin{array}{l}\text { GI-Inh. } \\
(\%)\end{array}$ & $\begin{array}{l}\mathrm{MIC} \\
(\mathrm{mg} / \mathrm{mL})\end{array}$ & $\begin{array}{l}\text { GI-Inh. } \\
(\%)\end{array}$ & $\begin{array}{l}\mathrm{MIC} \\
(\mathrm{mg} / \mathrm{mL})\end{array}$ & $\begin{array}{l}\text { GI-Inh. } \\
(\%)\end{array}$ & $\begin{array}{l}\begin{array}{l}\text { MIC } \\
(\mathrm{mg} / \mathrm{mL})\end{array} \\
\end{array}$ & $\begin{array}{l}\text { GI-Inh. } \\
(\%)\end{array}$ & $\begin{array}{l}\begin{array}{l}\mathrm{MIC} \\
(\mathrm{mg} / \mathrm{mL})\end{array} \\
\end{array}$ & $\begin{array}{l}\text { GI-Inh. } \\
(\%)\end{array}$ & $\begin{array}{l}\begin{array}{l}\text { MIC } \\
(\mathrm{mg} / \mathrm{mL})\end{array} \\
\end{array}$ & $\begin{array}{l}\text { GI-Inh. } \\
(\%)\end{array}$ & $\begin{array}{l}\begin{array}{l}\text { MIC } \\
(\mathrm{mg} / \mathrm{mL})\end{array} \\
\end{array}$ & $\begin{array}{l}\text { GI-Inh. } \\
(\%)\end{array}$ & $\begin{array}{l}\begin{array}{l}\text { MIC } \\
(\mathrm{mg} / \mathrm{mL})\end{array} \\
\end{array}$ & $\begin{array}{l}\text { GI-Inh. } \\
(\%)\end{array}$ \\
\hline $\mathrm{CH}^{\mathrm{b}}+\mathrm{P} 2^{\mathrm{e}}$ & $\begin{array}{l}0.015 \pm \\
0.007\end{array}$ & 58.3 & $\begin{array}{l}0.015 \pm \\
0.007\end{array}$ & 58.3 & $\begin{array}{l}0.007 \pm \\
0.0036\end{array}$ & 66.6 & $\begin{array}{l}0.003 \pm \\
0.0015\end{array}$ & 75.0 & $\begin{array}{l}0.015 \pm \\
0.007\end{array}$ & 58.3 & $\begin{array}{l}0.031 \pm \\
0.015\end{array}$ & 50.0 & $\begin{array}{l}0.007 \pm \\
0.0035\end{array}$ & 66.6 & $\begin{array}{l}0.003 \pm \\
0.0015\end{array}$ & 75.0 & $\begin{array}{l}0.015 \pm \\
0.007\end{array}$ & 58.3 \\
\hline $\mathrm{CH}+\mathrm{P}^{\mathrm{f}}$ & $\begin{array}{l}0.003 \pm \\
0.0015\end{array}$ & 75.0 & $\begin{array}{l}0.007 \pm \\
0.0035\end{array}$ & 66.6 & $\begin{array}{l}0.003 \pm \\
0.0015\end{array}$ & 75.0 & $\begin{array}{l}0.007 \pm \\
0.0035\end{array}$ & 66.6 & $\begin{array}{l}0.031 \pm \\
0.015\end{array}$ & 50.0 & $\begin{array}{l}0.007 \pm \\
0.0035\end{array}$ & 66.6 & $\begin{array}{l}0.003 \pm \\
0.0015\end{array}$ & 75.0 & $\begin{array}{l}0.003 \pm \\
0.0015\end{array}$ & 75.0 & $\begin{array}{l}0.007 \pm \\
0.0035\end{array}$ & 66.6 \\
\hline $\begin{array}{l}\mathrm{CH}+\mathrm{P} 2 / \\
\mathrm{CH}+\mathrm{P} 1\end{array}$ & 9.00 & & 2.143 & & 2.334 & & 0.429 & & 0.484 & & 4.429 & & 2.334 & & 1.000 & & 2.143 & \\
\hline$t$-test & 0.025 & & 0.025 & & 0.025 & & 0.025 & & 0.025 & & 0.025 & & 0.025 & & 0.025 & & 0.025 & \\
\hline CI & 1.8413 & & 1.9484 & & 1.8983 & & 1.8983 & & 1.9224 & & 1.8428 & & 1.8983 & & 4.3027 & & 1.9484 & \\
\hline $\mathrm{FoH}^{\mathrm{c}}+\mathrm{P} 2$ & $\begin{array}{l}0.007 \pm \\
0.0035\end{array}$ & 66.6 & $\begin{array}{l}0.003 \pm \\
0.0015\end{array}$ & 75.0 & $\begin{array}{l}0.007 \pm \\
0.0035\end{array}$ & 66.8 & $\begin{array}{l}0.007 \pm \\
0.0035\end{array}$ & 66.6 & $\begin{array}{l}0.003 \pm \\
0.0015\end{array}$ & 75.0 & $\begin{array}{l}0.007 \pm \\
0.0035\end{array}$ & 66.6 & $\begin{array}{l}0.003 \pm \\
0.0015\end{array}$ & 75.0 & $\begin{array}{l}0.007 \pm \\
0.0035\end{array}$ & 66.6 & $\begin{array}{l}0.003 \pm \\
0.0015\end{array}$ & 75.0 \\
\hline $\mathrm{FoH}+\mathrm{P} 1$ & $\begin{array}{l}0.003 \pm \\
0.0015\end{array}$ & 75.0 & $\begin{array}{l}0.007 \pm \\
0.0035\end{array}$ & 66.6 & $\begin{array}{l}0.007 \pm \\
0.0035\end{array}$ & 66.6 & $\begin{array}{l}0.007 \pm \\
0.0035\end{array}$ & 66.6 & $\begin{array}{l}0.015 \pm \\
0.007\end{array}$ & 58.0 & $\begin{array}{l}0.003 \pm \\
0.0015\end{array}$ & 75.0 & $\begin{array}{l}0.007 \pm \\
0.0035\end{array}$ & 66.6 & $\begin{array}{l}0.007 \pm \\
0.0035\end{array}$ & 66.6 & $\begin{array}{l}0.003 \pm \\
0.0015\end{array}$ & 75.0 \\
\hline $\begin{array}{l}\mathrm{FoH}+\mathrm{P} 2 / \\
\mathrm{FoH}+\mathrm{P} 1\end{array}$ & 2.334 & & 0.429 & & 1.000 & & 1.000 & & 0.200 & & 2.334 & & 0.429 & & 1.000 & & 1.000 & \\
\hline$t$-test & 0.025 & & 0.025 & & 0.025 & & 0.025 & & 0.025 & & 0.025 & & 0.025 & & 0.025 & & 0.025 & \\
\hline $\mathrm{CI}$ & 1.8983 & & 1.8983 & & 4.3027 & & 4.3027 & & 1.8413 & & 1.8983 & & 1.8983 & & 4.3027 & & 4.3027 & \\
\hline $\mathrm{F} 1 \mathrm{H}^{\mathrm{d}}+\mathrm{P} 2$ & $\begin{array}{l}0.031 \pm \\
0.007\end{array}$ & 50.0 & $\begin{array}{l}0.015 \pm \\
0.007\end{array}$ & 58.3 & $\begin{array}{l}0.015 \pm \\
0.007\end{array}$ & 58.3 & $\begin{array}{l}0.031 \pm \\
0.015\end{array}$ & 50.0 & $\begin{array}{l}0.031 \pm \\
0.015\end{array}$ & 58.3 & $\begin{array}{l}0.015 \pm \\
0.007\end{array}$ & 58.3 & $\begin{array}{l}0.015 \pm \\
0.007\end{array}$ & 58.3 & $\begin{array}{l}0.062 \pm \\
0.015\end{array}$ & 41.6 & $\begin{array}{l}0.015 \pm \\
0.007\end{array}$ & 58.3 \\
\hline $\mathrm{F} 1 \mathrm{H}+\mathrm{P} 1$ & $\begin{array}{l}0.015 \pm \\
0.007\end{array}$ & 58.3 & $\begin{array}{l}0.015 \pm \\
0.007\end{array}$ & 58.3 & $\begin{array}{l}0.031 \pm \\
0.015\end{array}$ & 50.0 & $\begin{array}{l}0.031 \pm \\
0.015\end{array}$ & 50.0 & $\begin{array}{l}0.031 \pm \\
0.015\end{array}$ & 50.0 & $\begin{array}{l}0.062 \pm \\
0.015\end{array}$ & 41.6 & $\begin{array}{l}0.015 \pm \\
0.007\end{array}$ & 58.3 & $\begin{array}{l}0.062 \pm \\
0.015\end{array}$ & 41.6 & $\begin{array}{l}0.031 \pm \\
0.015\end{array}$ & 41.6 \\
\hline $\begin{array}{l}\mathrm{F} 1 \mathrm{H}+\mathrm{P} 2 / \\
\mathrm{FlH}+\mathrm{P} 1\end{array}$ & 2.067 & & 1.000 & & 0.484 & & 1.000 & & 1.000 & & 0.242 & & 1.000 & & 1.000 & & 0.484 & \\
\hline$t$-test & 0.025 & & 0.025 & & 0.025 & & 0.025 & & 0.025 & & 0.025 & & 0.025 & & 0.025 & & 0.025 & \\
\hline CI & 4.3027 & & 4.3027 & & 1.9224 & & 4.3027 & & 4.3027 & & 1.9224 & & 4.3027 & & 4.3027 & & 4.3027 & \\
\hline
\end{tabular}

$\mathrm{a}=$ meticillin-resistant Staphylococcus aureus; $\mathrm{b}=$ chestnut honey; $\mathrm{c}=$ forest honey; $\mathrm{d}=$ flower honey; $\mathrm{e}=\mathrm{PBS}$ propolis extract $\mathrm{Lj}$. Center $\mathrm{pH}=8.0 ; \mathrm{f}=\mathrm{WSP}$ Greit 120 . 


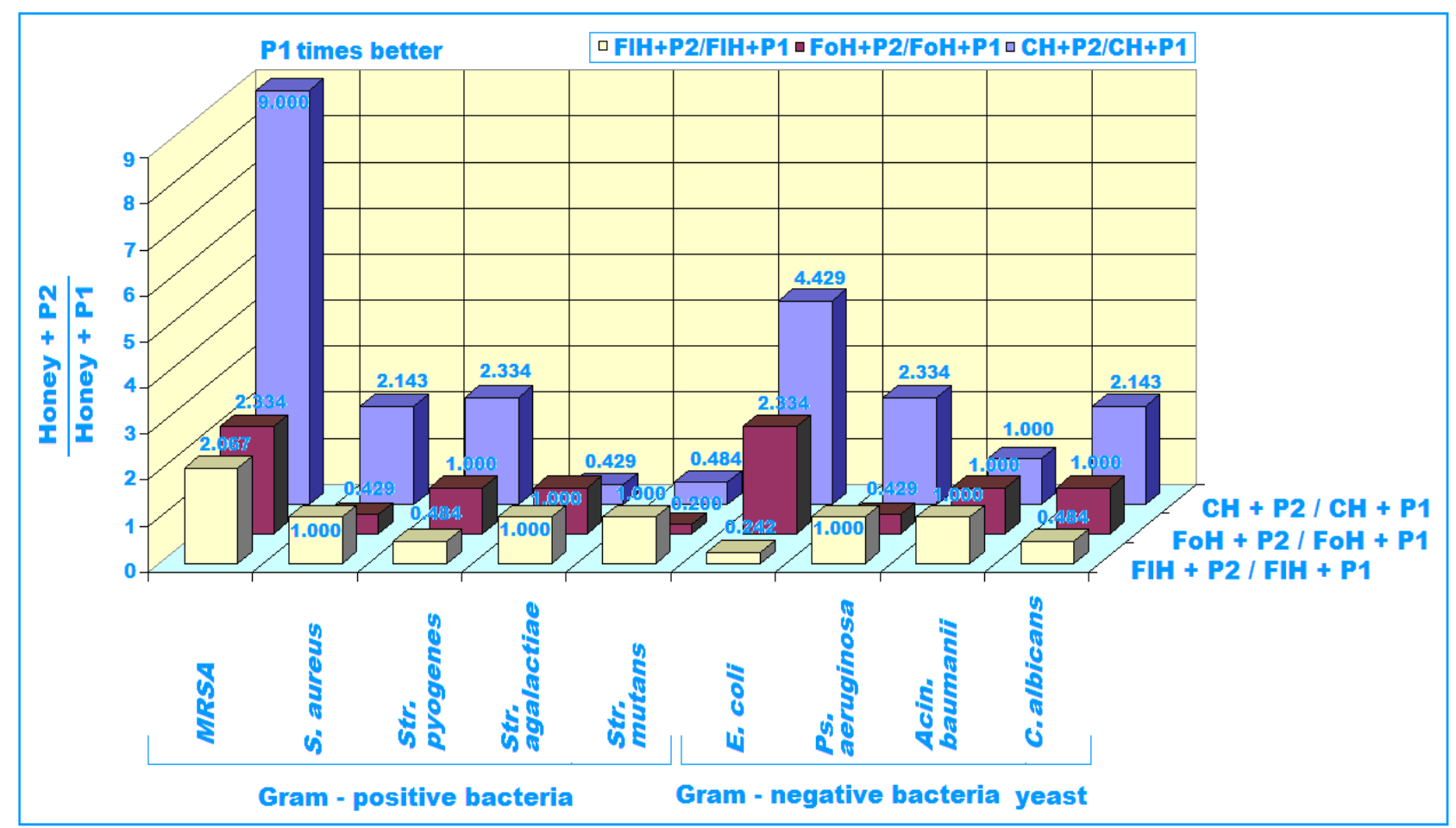

Fig. 8 The effectiveness of $P 1$ versus $P 2$ for the antimicrobial activity (MIC in $\mathrm{mg} / \mathrm{mL}$ ) against Gram-positive, Gram-negative bacteria and yeast $C$. albicans of Slovenian $\mathrm{CH}$, FoH and FlH .

phenolic agents show the presence of: caffeic acid $2.44 \pm 0.18 \mathrm{mg} / \mathrm{mL}$, caffeic acid $11.43 \pm 0.11 \mathrm{mg} / \mathrm{mL}$, chrysin $0.15 \pm 0.008 \mathrm{mg} / \mathrm{mL}$, pinocembrin $0.46 \pm$ $0.004 \mathrm{mg} / \mathrm{mL}$ and galangin $0.62 \pm 0.05 \mathrm{mg} / \mathrm{mL}$. In the experiments performed by Mello et al. [26] it was shown that water extracts of propolis prepared in $\mathrm{pH}=$ 8.0 show stronger antimicrobial activity than those prepared in $\mathrm{pH} 6.4$ and 7.2. This was the basis for the experiments in which the PBS extract of P2 was prepared. This propolis extract has comparable antimicrobial activities with P1 from BNatural.

The antibacterial effect of honey is associated with its high osmolarity, low $\mathrm{pH}$ and hydrogen peroxide content which is called inhibin factor. Non-peroxide antibacterial substances such as aromatic acids, phenolics, flavonoids are other groups of compounds of antibacterial effectors of honey. The results obtained showed that the total phenolic content (mg GAE/100 g honey) determined by the modified FC method varied among the different types of honey. The total phenolic content of Turkish honey was between $1.50-108.21 \mathrm{mg}$
GAE/100 $\mathrm{g}$ of honey. The total phenolic substances were highest in $\mathrm{CH}(46.97 \pm 17.52 \mathrm{mg}$ GAE$/ 100 \mathrm{~g})$ followed by FoH $(24.2 \pm 0.6 \mathrm{mg} \mathrm{GAE} / 100 \mathrm{~g})$. The lowest values were found in $\mathrm{FlH}$ with $11.11 \pm 0.019 \mathrm{mg}$ GAE/100 g. When the Slovenian kinds of honey were analyzed, the most important factors are their flavonoid content and the acidity of honey, with a pH between 3.2 and 4.5. The $\mathrm{pH}$ is an important active factor in honey's antibacterial activity since most bacteria grow in a $\mathrm{pH}$ range between 6.5 and 7.5. So for $\mathrm{CH}$ the flavonoid content is $191.7 \pm 26.8 \mathrm{mg} / \mathrm{mL}$ and $\mathrm{pH} 5.51 \pm 0.42$. For FoH the flavonoid content is $210.4 \pm 36.4 \mathrm{mg} / \mathrm{mL}$ and $\mathrm{pH} 4.77 \pm 0.21$. And for FlH the flavonoid content is $138.0 \pm 29.7 \mathrm{mg} / \mathrm{mL}$ with $\mathrm{pH} 4.35 \pm 0.24$, as it was found by Bertoncelj et al. [27] and Strelec et al. [28]. The flavonoid content correlates with antioxidant and antimicrobial activity.

The fact that different sorts of propolis or propolis' extracts affect different kind of honey is not new. So it was found that $\mathrm{P} 1$ enhances the antimicrobial activity of FoH from Italy and Spain [29]. In additional 
experiments, it was studied at first the antimicrobial activity of Slovenian $\mathrm{CH}, \mathrm{FoH}$ and $\mathrm{FlH}$. Interestingly, quite strong $\mathrm{MIC}$ in $\mathrm{mg} / \mathrm{mL}$ was found for $\mathrm{CH}$ and FoH, but very weak MIC in $\mathrm{mg} / \mathrm{mL}$ was found for $\mathrm{FlH}$. To measure the enhancement with $\mathrm{P} 1$ or P2 it was prepared the mixture of different Slovenian honeys: $\mathrm{CH}, \mathrm{FoH}$ and $\mathrm{FlH}$ with $10 \%$ of $\mathrm{P} 1$ or $\mathrm{P} 2$ and then measured their antimicrobial activity and compared this with antimicrobial activity (MIC) in $\mathrm{mg} / \mathrm{mL}$ of $\mathrm{CH}, \mathrm{FoH}$ and $\mathrm{FlH}$. The best results were obtained when the $\mathrm{CH}$ was mixed with $10 \%$ of $\mathrm{P} 1$ or $\mathrm{P} 2$. The best was the addition of $\mathrm{P} 1$ in a way of enhancement of the antimicrobial activity of $\mathrm{CH}$ (Fig. 5) followed by mixtures of $\mathrm{FoH}$ and $\mathrm{FlH}$ with $10 \%$ of P2 (Figs. 6 and 7). Finally, the effectiveness of P2 versus P1 was calculated (Fig. 8). It seems that the enhancement of antimicrobial activity depends on the sort of honey and also on the nature of propolis extracts P1 or P2. It was also found by Sarikaya et al. [30] that the content of phenolics caffeic acid in $\mathrm{CH}(0.6 \pm 0.02 \mathrm{mg} / \mathrm{mL})$ and much higher in propolis $(2.3 \pm 1.12 \mathrm{mg} / \mathrm{mL})$, could be the factors of enhancement of antioxdiative activity and consequently antimicrobial activity of mixture of $\mathrm{CH}$ and propolis. In comparison, in Slovenian $\mathrm{CH}$ there was $0.87 \pm 0.04 \mathrm{mg} / \mathrm{mL}$ of caffeic acid and much higher in P1 $3.11 \pm 0.92 \mathrm{mg} / \mathrm{mL}$ suggesting about the enhancement of antimicrobial activity.

\section{Conclusions}

From the performed experimental study, the following conclusions may be drawn:

(1) The P1 added to Slovenian $\mathrm{CH}$ is better than P2 added to $\mathrm{CH}$ as follows: for Gram-positive bacteria, $9.00 \times$ (MRSA), 2.143× (S. aureus), 2.334× (Str. pyogenes), $0.429 \times$ (Str. agalactiae), 0.484× (Str. mutans); for Gram-negative bacteria, 4.429× (E. coli), $2.334 \times($ Ps. aeruginosa $), 1.000 \times($ Acin. baumanii $)$ and for $C$. albicans $2.143 \times$.

(2) The P1 added to Slovenian FoH is better than P2 added to FoH as follows: for Gram-positive bacteria, $2.334 \times(\mathrm{MRSA}), 0.492 \times(S$. aureus $), 1.000 \times$ (Str. pyogenes), $1.000 \times($ Str. agalactiae) and $0.200 \times$ (Str. mutans); for Gram-negative bacteria, 2.334× (E. coli), 0.429× (Ps. aeruginosa), 1.000× (Acin. baumanii) and for C. albicans $1.000 \times$.

(3) The P1 added to FlH is better than P2 added to $\mathrm{FlH}$ as follows: for Gram-positive bacteria, 2.067× (MRSA), $1.000 \times($ S. aureus $), 0.484 \times($ Str. pyogenes $)$, $1.000 \times($ Str. agalactiae $)$ and $1.000 \times($ Str. mutans $)$; for Gram-negative bacteria, $0.242 \times($ E. coli $), 1.000 \times(P s$. aeruginosa), 1.000× (Acin. baumanii) and for $C$. albicans $0.484 \times$.

(4) The enhancement of antimicrobial activity depends on sort and phenolic composition of honeys and and also on the nature of propolis extracts $\mathrm{P} 1$ or $\mathrm{P} 2$.

\section{Acknowledgments}

The presented research was supported in the frame of Croatian Institute for Experimental and Translational Oncology, in Project "Oncolytic Newcastle Disease Virus in the Veterinary Medicine" and through the Crodux-plini, Savska Opatovina, 10040 Zagreb, Croatia. Authors are indebted to Tomaž Velnar for English suggestions.

\section{References}

[1] Bankova, S. V., De Castro, S. L., and Marcucci, M. C. 2000. "Propolis: Recent Advances in Chemistry and Plant Origin." Apidologie 31: 3-15.

[2] Krell, R. 1996. "Value-Added Products from Beekeeping." FAO Agricultural Services Bulletin No. 124. Accessed on October 28, 2013. http://www.fao.org/docrep/w0076e/w0076e00.htm.

[3] Marcucci, M., Woisky, R., and Salatino, A. 1998. "Use of Aluminium Chloride in the Flavonoids Quantification of Propolis Samples." Mensagem doce 46: 3-9. (in Portuguese)

[4] Park, Y., Ikegaki, M., Abreu, J., and Alcici, N. 1998. "Study of the Preparation of Propolis Extracts and Its Applications." Ciencia e Tecnologia de Alimentos 18: 313-8. (in Portuguese)

[5] Chailou, L., and Nazareno, M. 2009. "Bioactivity of Propolis from Santiago del Estero, Argentina, Related to Their Chemical Composition." Food Science and Technology 42: 1422-7. 
[6] Gülçin, I., Bursal, E., Hilal, M., Bilsel, M. S., and Gören, C. A. 2010. "Polyphenol Contents and Antioxidant Activity of Lyophilized Aqueous Extract of Propolis from Erzurum, Turkey." Food and Chemical Toxicology 48: 2227-38.

[7] Miguel, M., Nunes, S., Dandlen, S., Cavaco, A., and Antunes, M. 2010. "Phenols and Antioxidant Activity of Hydroalcoholic Extracts of Propolis from Algarve, South of Portugal." Food and Chemical Toxicology 48: 3418-23.

[8] Burdock, G. A. 1998. "Review of the Biological Properties and Toxicity of Bee Propolis." Food and Chemical Toxicology 36: 347-63.

[9] Vargas, A. C., Loguercio, A. P., Witt, N. M., Costa, M. M., Silva, M. S., and Viana, L. R. 2004. "Alcoholic Propolis Extract: Antimicrobial Activity." Ciencia Rural 34: 159-63. (in Spanish)

[10] Park, Y. K., Alencar, S. M., and Aguiar, C. L. 2002. "Botanical Origin and Chemical Composition of Brazilian Propolis." Journal of Agricultural and Food Chemistry 50: 2502-6.

[11] Osés, S. M., Pascual-Maté, A., De la Fuente, D., De Pablo, A., Fernández-Muiño, M. A., and Sancho, M. T. 2016. "Comparison of Methods to Determine Antibacterial Activity of Honeys against Staphylococcus aureus." NJAS-Wageningen Journal of Life Sciences 78: 29-33.

[12] Weston, R. J. 2000. "The Contribution of Catalase and Other Natural Products to the Antibacterial Activity of Honey: A Review." Food Chemistry 71 (2): 235-9.

[13] Mavric, E., Wittmann, S., Barth, G., and Henle, T. 2008. "Identification and Quantification of Methylglyoxal as the Dominant Antibacterial Constituent of Manuka (Leptospermum scoparium) Honeys from New Zealand." Mol. Nutr. Foods Res. 52 (4): 483-9.

[14] Bang, L. M., Buntting, C., and Molan, P. C. 2003. "The Effect of Dilution on the Rate of Hydrogen Peroxide Production in Honey and Its Implications for Wound Healing." J. Altern. Complement. Med. 9 (2): 267-73.

[15] Lusby, P. E., Coombes, A. L., and Wilkinson, J. M. 2005. "Bactericidal Activity of Different Honeys against Pathogenic Bacteria." Arch. Med. Res. 36 (5): 464-7.

[16] Lusby, P. E., Coombes, A., and Wilkinson, J. M. 2002. "Honey: A Potent Agent for Wound Healing?" Journal of Wound Ostomy and Continence Nursing 9 (6): 295-300.

[17] Fachini, A., and Volpi, N. 2012. "M.E.D. Integral Propolis: The Evolution of the Working Process in Natural Complex Matrix." Directory Ingredient 20-4.

[18] Volpi, N., and Fachini, A. 2017. "Integral Extracts of Rich Propolis in Polyphenols and Equipped with Antibacterial Activity and Its Application in Prevention and Treatment of Infectious Processes of Bacterial
Origin." Office of Italian Patents and Trademarrs No. 0001425516, 02/02/2017.

[19] Urushisaki, T., Takemura, T., Tazawa, S., Fukuoka, M., Hosokawa-Muto, J., Araki, Y., and Kazuo Kuwata, K. 2011. "Caffeoylquinic Acids Are Major Constituents with Potent Anti-influenza Effects in Brazilian Green Propolis Water Extract." Evidence-Based Complementary and Alternative Medicine 2011 (11). Article ID 254914, doi:10.1155/2011/254914.

[20] Blainski, A., Lopes, G. C., and Palazzo de Mello, J. C. 2013. "Application and Analysis of the Folin Ciocalteu Method for the Determination of the Total Phenolic Content from Limonium brasiliense L." Molecules 18: 6852-65.

[21] Filipič, B., Ciglar Grozdanić, I., Gottstein, Ž., Sindik-Milošević, T., Sladoljev, S., Mazija, H., Koren, S., and Šooš, E. 2007. "HuIFN- $\alpha$ N3 Affects the Replication of Avian Influenza (H5N2) Virus in the Embryonated Chicken Eggs." In Proceedings of Poultry Days VII, 223-9.

[22] Shi, S., Huang, K., Zhang, Y., Zhao, Y., and Du, Q. 2007. "Purification and Identification of Antiviral Components from Laggera Periodontal by High-Speed Countercurrent Chromatography." Journal of Chromatography B 859 (1): 119-24.

[23] Prix, L., Maier, J., Jahn, G., and Hamprecht, K. 1998. “A Simplified Assay for Screening of Drug Resistance of Cell-Associated Cytomegalovirus Strains." Journal of Clinical Virology 11 (8): 29-37.

[24] Bertoncelj, J. 2008. "Identification and Quantification of Some Antioxidants in Slovenian Honeys." Doctoral dissertations, Biotechnical Faculty, University of Ljubljana, Slovenia.

[25] Fujimoto, T., Nakamura, J., and Matsuka, M. 2001. "Diversity of Propolis, Part 1. Propolis from the World." Honeybee Science 22 (1): 9-16.

[26] Mello, B. C., Kakuda, B. S., and Hubinger, P. M. 2011. "Influence of $\mathrm{pH}$ Variation during Propolis Extraction with the Use of Water as Solvent." In Proceedings of the 11th International Congress on Engineering and Food (ICEF11), Volume III, 2187-96.

[27] Bertoncelj, J., Golob, T., Kropf, U., and Korosec, M. 2011. "Characterisation of Slovenian Honeys on the Basis of Sensory and Physicochemical Analysis with a Chemometric Approach." International Journal of Food Science and Technology 46: 1661-71.

[28] Strelec, I., Cervar, B., Kovač, L., Bilić Rajs, B., Primorac, L., and Flanjak, I. 2018. "Glucose Oxidase Activity and Hydrogen Peroxide Concentration in Croatian Honeys." Croat. J. Food Sci. Technol. 10 (1): 33-41.

[29] Filipič, B., Gradišnik, L., Ružić-Sabljić, E., Trtnik, B., Pereyra, A., Jaklič, D., Kopinč, R., Potokar, J., Puzić, A., 


\section{Chestnut, Forest and Flower Honeys}

and Mazija, H. 2016. "Water Soluble Propolis and Royal Jelly Enhance the Antimicrobial Activity of Honeys and Promote the Growth of Human Macrophage Cell Line." Journal of Agricultural Science and Technology B 6 : $35-47$.
[30] Sarikaya, O. A., Ulusoy, E., Öztürk, N., Tuncel, M., and Kolayli, S. 2009. "Antioxidant Activity and Phenolic Constituents of Chestnut (Castania sativa Mill.) Honey and Propolis." Journal of Food Biochemistry 33 (1): 470-81. 